NBER WORKING PAPER SERIES

\title{
MIGRATION AS A TEST OF THE HAPPINESS SET POINT HYPOTHESIS: EVIDENCE FROM IMMIGRATION TO CANADA
}

\author{
John F. Helliwell \\ Aneta Bonikowska \\ Hugh Shiplett \\ Working Paper 22601 \\ http://www.nber.org/papers/w22601 \\ NATIONAL BUREAU OF ECONOMIC RESEARCH \\ 1050 Massachusetts Avenue \\ Cambridge, MA 02138 \\ September 2016
}

The authors are grateful to Statistics Canada and the Gallup Organization for access to data, and to colleagues and seminar participants at Statistics Canada, CIFAR, the Vancouver School of Economics and the June 2016 meetings of the Canadian Economics Association, and especially Nicole Fortin, Feng Hou, Thomas Lemieux, and Michael Wolfson for comments on earlier versions. Responsibility for opinions and errors remains with the authors. The views expressed herein are those of the authors and do not necessarily reflect the views of the National Bureau of Economic Research.

NBER working papers are circulated for discussion and comment purposes. They have not been peer-reviewed or been subject to the review by the NBER Board of Directors that accompanies official NBER publications.

(C) 2016 by John F. Helliwell, Aneta Bonikowska, and Hugh Shiplett. All rights reserved. Short sections of text, not to exceed two paragraphs, may be quoted without explicit permission provided that full credit, including $(\odot$ notice, is given to the source. 
Migration as a Test of the Happiness Set Point Hypothesis: Evidence from Immigration to Canada

John F. Helliwell, Aneta Bonikowska, and Hugh Shiplett

NBER Working Paper No. 22601

September 2016

JEL No. F22,I31,J61

\section{ABSTRACT}

Strong versions of the set point hypothesis argue that subjective well-being measures reflect each individual's own personality and that deviations from that set point will tend to be short-lived, rendering them poor measures of the quality of life. International migration provides an excellent test of this hypothesis, since life circumstances and average subjective well-being differ greatly among countries. Life satisfaction scores for immigrants to Canada from up to 100 source countries are compared to those in the countries where they were born. With or without various adjustments for selection effects, the average levels and distributions of life satisfaction scores among immigrants mimic those of other Canadians rather than those in their source countries and regions. This supports other evidence that subjective life evaluations, especially when averaged across individuals, are primarily driven by life circumstances, and respond correspondingly when those circumstances change.

John F. Helliwell

Vancouver School of Economics

University of British Columbia

6000 Iona Drive

Vancouver, BC V6T 1L4

CANADA

and NBER

john.helliwell@ubc.ca

Aneta Bonikowska

Social Analysis and Modelling Division

Statistics Canada

100 Tunney's Pasture Driveway

Ottawa, Ontario K1A 0T6

CANADA

aneta.bonikowska@canada.ca
Hugh Shiplett

Vancouver School of Economics

University of British Columbia

6000 Iona Drive

Vancouver, BC V6T 1L4

CANADA

hugh.shiplett@gmail.com 


\section{Introduction}

It has increasingly been suggested that measures of subjective well-being could provide umbrella measures of human progress, able to capture the combined effects of income, health and the social context as supports for better lives. But over several decades others have argued instead that life evaluations change only temporarily with changes in life circumstances, reverting thereafter to a set point that varies among individuals based on personality differences that in turn may be driven by genetic differences. There is a growing literature attempting to show which life events, if any, are followed by sustained changes in life evaluations. If the range of such changes is sufficiently broad and representative of those variables generally agreed to contribute to a good life, then the set point hypothesis need not stand in the way of using life evaluations more generally as measures of human progress.

Various life events, including serious health problems, marriage, divorce, and unemployment have been shown to have continuing consequences for life evaluations. There has been much less study of the extent to which people are affected over the longer term by the social and institutional contexts in which they live. Migration, especially international migration, takes people from one social context into another, and hence offers a potentially powerful test. The set point hypothesis supposes that the life evaluations of migrants might well rise or fall during the migration process, reflecting some mix of the psychological costs of uprooting and the expected benefits from moving to someplace better, but would eventually return to their pre-established set points. On the other hand, if life evaluations are affected in the long term by the institutional and social contexts in which people live, it might be expected that the average life evaluations of migrants would come to match those of others in their new communities.

International migration provides a much more promising test-bed for research than does internal migration, since there is much less difference in life evaluations among cities or regions within a country than between countries. For example, the range of average life evaluations among cities in Canada, or among states in the United States, is only one tenth as large as among the nations surveyed by the Gallup World Poll. There are similarly larger international differences in the institutions and social contexts that have been found to support high life evaluations. Thus international migration takes people from countries with widely varying average life evaluations. 
In the case we are studying in this paper, the immigrants are coming to Canada from up to 100 different countries, with life evaluations ranging from less than half those in Canada up to Canadian levels and beyond. If the migrant groups are sufficiently large, and sufficiently representative of the populations in the source countries, then their subsequent life evaluations in Canada will provide a powerful test of the set point hypothesis. If the social and institutional contexts provide strong long-term support for subjective well-being, then it should be expected that migrants would in the longer term report life evaluations more like those in Canada than in their countries of birth.

\section{Literature Review}

The idea that life events affect the happiness of individuals only in a transitory way first gained prominence in adaptation-level theory (Brickman and Campbell, 1971). This view was supported by the widely cited subsequent finding that lottery winners reported levels of happiness that were not higher than controls, while recently paraplegic accident victims reported levels of happiness that were higher than expected (Brickman, Coates, and Janoff-Bulman, 1978). In reality, however, the findings of Brickman et al. (1978) were only partially in accordance with adaptation theory. Most notably, although the accident victims did report levels of affect above neutrality, which was unexpected, they were still substantially lower on average than controls. Lucas (2007) has since confirmed that life satisfaction not only drops with the onset of disability, but also does so more dramatically for more severe disabilities. What's more, these decreases remained remarkably stable for several years thereafter, and showed no sign of attenuation. Other longitudinal studies have shown only partial adaptation to such other events as divorce, widowhood, and unemployment (Lucas et al., 2004; Lucas, 2005; Luhmann et al., 2012). Even in cases, such as marriage, where adaptation has appeared to be complete in some samples, this can conceal divergence at the individual level or in different sub-populations (Headey, Muffels, and Wagner, 2013; Lucas et al., 2004; Luhmann et al., 2012). Even in those longitudinal studies where the married have been seen to revert to pre-marital happiness levels, the effect is restored when the married are compared with unmarried others of the same age, who have on average been sliding down a U-shape linking life evaluations with age in many countries (Yap et al., 2012; Grover and Helliwell, 2014). 
Set point theory in its strong form, in which all individuals have their own fixed long-term levels of happiness or satisfaction, from which they deviate only temporarily, was developed in large part from the results of Lykken and Tellegen (1996). Using data from the Minnesota Twin Registry, they claimed that around half of the variation in happiness at any given time could also be attributed to genetics, and that up to $80 \%$ of the variation in the 'stable component' was heritable. There are several reasons, however, to take this result with caution. The first claim was based on the correlations between levels of self-reported contentment among monozygotic twins raised apart. This, however, does not necessarily imply that potential happiness is itself a stable personality trait. Other genetically determined traits which are conducive to happiness in a particular context could generate such a correlation, while still allowing for happiness to be intrinsically variable. Furthermore, the salience of this genetic factor depends crucially on the degree of environmental variability faced by Minnesotan twins. If their environments were fairly comparable, then it is natural to expect that the role of genetics would appear comparatively large. Lastly, with only one follow-up measurement, it was not possible to distinguish between genuine stability and co-movement between the monozygotic twins over time.

Longitudinal and panel datasets have tended not to agree with the claim that an individual's life satisfaction cannot change over the long term. Retest correlation levels for life satisfaction decline unambiguously over time. A meta-analysis by Veenhoven (1994) found that test-retest correlations declined from around .6 for shorter time spans (months) to levels as low as .15 after ten to fifteen years. Similarly, using data from the German Socio-Economic Panel (GSOEP) from 1984 to 2000, Fujita and Diener (2005) found that the correlation between observations of the same individual's life satisfaction over time declined from .79 to .34 after 16 years even after allowance for measurement error. Furthermore, approximately one quarter of individuals in the GSOEP recorded changes in their five-year average for life satisfaction between the beginning and the end of the observation period which were significant at $\mathrm{p}<.05$, five times as many as would have been predicted under the set point hypothesis. In many cases, changes were also qualitatively large, with close to $10 \%$ of respondents recording changes of 3 points or more on a 10-point scale. Subsequent analysis of the GSOEP covering 1985 to 2005 yielded similar results (Headey, 2008). Changes in life satisfaction over time in the GSOEP, as well as in similar panels from Australia and the United Kingdom, can also be predicted by differences in altruistic vs. 
materialistic goals, social participation, partner's personality, working hours (above or below desired levels), and exercise (Headey et al., 2013).

In spite of robust evidence that life satisfaction is only moderately stable in the long run, individual-level regressions based on observed differences in material conditions tend to have relatively limited explanatory power (Diener et al., 1999; Fujita and Diener, 2005; Headey et al., 2013). Whether this is because material conditions and environment are unimportant, or because important features of the environment, and especially the quality of the social context, have not been adequately captured remains an open question. More nuanced measurements of financial deprivation can perform substantially better than income alone (Christoph, 2010), while levels of health and social capital have been shown to add substantially to explaining differences in subjective well-being among individuals as well as among communities and countries (Helliwell and Putnam, 2004).

International migration offers a valuable opportunity to observe the effects of large changes in the material and social environment. The relationship between migration and subjective wellbeing has only recently become the focus of empirical study (Bartram, 2011, 2015; De Jong, Chamratrithirong, and Tran, 2002; Dinesen, 2012; Frank, Hou, and Schellenberg, 2015; Ivlevs, 2015; Melzer, 2011; Melzer and Muffels, 2012; Nowok et al., 2013; Olgiati, Calvo, and Berkman, 2013; Senik, 2014; Switek, 2016). In the most commonly studied case of migrationimmigration into countries with relatively high subjective well-being levels - it has routinely been observed that international migrants report lower life satisfaction on average than natives of their host country (de Vroome and Hooghe, 2014; Frank et al., 2016; Safi, 2010). In several instances, this gap was explained by accounting for the effects of perceived discrimination (Safi, 2010) or differences in occupational status and social support (de Vroome and Hooghe, 2014).

Previous research on the life satisfaction of international migrants has not focused on the implications for set point theory, although some recent research considers the extent to which social norms and subjective well-being are sustained during the migration process, and hence could reflect deeply ingrained aspects of culture. In recent research using data from the European Social Survey, Senik (2014) argues for a cultural component in subjective well-being. She finds 
that emigrants from France, where average life satisfaction is significantly below predicted levels in some international happiness regressions ${ }^{1}$, remain below the new average in their host countries. This relationship also held, in terms of its sign, for emigrants from six of the seven western-European countries studied. Interaction terms for immigrants who had resided in their host country for 10 or 20 years, however, did indicate a degree of convergence toward the national-level fixed effects for natives. In the case of migrants from France, where social trust levels are low, this pattern is consistent with what would be predicted by other studies showing that migrants have social trust assessments partway between those in their countries of birth and of residence (Dinesen, 2012; Soroka et al., 2007; Rice and Feldman, 1997). Similar results for life satisfaction, which depends heavily on social trust, have also been achieved using data from the European Values Survey, showing life satisfaction for European migrants tended to be an 'alloy' incorporating the levels in both the host and origin countries (Voicu and Vasile, 2014).

Helliwell, Wang and Xu (2016) test the relative importance of culture versus experience by examining the immigration footprints for social trust, generosity, and confidence in specific national institutions, making use of a fully global sample involving immigrants to and from more than 130 countries. These results support the notion that social norms are deeply rooted in longstanding cultures, yet are nonetheless subject to adaptation when there are major changes in the surrounding circumstances and environment. In particular, the effect of source-country social trust is strongly significant, with a size about one-third as large as that from trust levels in the destination countries where the migrant now lives. The footprint for another social norm, generosity, is also significant, although not as large. In contrast, trust in the national institutions of the new country, where footprint effects would not be expected, indeed shows no such effects.

Since there are few longitudinal data sets suitable for studying the effects of migration, the majority of studies listed above are based on analysis of cross-sectional differences between migrants and natives, or between more and less recent migrants. In a recent study of the emigration intentions of individuals from Europe and central Asia, Ivlevs (2015) found a U-shaped relationship between life satisfaction and emigration intentions, with those reporting

\footnotetext{
${ }^{1}$ However, France's observed subjective well-being is slightly above the predicted value in the World Happiness Report 2015 (Helliwell, Layard, and Sachs, eds., 2015, page 10 of Statistical Appendix).
} 
high or low levels of life satisfaction being more likely to declare a desire to emigrate than those reporting levels closer to the average. ${ }^{2}$ Interestingly, the U-shaped relationship has also been found among source countries, such that individuals from the least and most satisfied countries are more likely to emigrate than those from countries with average levels of life satisfaction in the middle of the distribution (Polgreen and Simpson, 2011).

Bartram (2011) suggested that economic migrants may self-select based on a higher ability to derive subjective well-being benefits from income, finding that the effect of income on life satisfaction for immigrants in the United States was significantly larger than for natives. The overall strength of the effect of absolute income, however, remained small even for the immigrants in Bartram's (2011) analysis. And a subsequent comprehensive international analysis of this phenomenon by Olgiati, Calvo, and Berkman (2013) failed to replicate this result in a 19-country sample from the Gallup World Poll, finding no significant difference in the effects of income for immigrants or the foreign born, including in the United States.

Several studies in recent years have made use of panel data sets to study the well-being effects of internal migration. Nowok, van Ham, Findlay, and Gayle (2013), using data on domestic migration from the British Household Panel, found that life satisfaction did not increase in the long run following a move, although moves were generally preceded by a substantial decrease in life satisfaction during the years immediately prior. This result, however, was based on a sample which included a large number of movers who had traveled very short distances, often less than five kilometers. Moves were often also coincident with changes in life circumstances, both positive and negative, such as marriage or separation. They did find, however, that the life satisfaction of those who moved only once increased following the move. Subsequently, Switek (2014) used data on inter-municipal migrants from the Swedish Young Adult Panel and found that, after controlling for changes in life circumstances, individuals who moved due to work experienced substantial and statistically significant increases in life satisfaction which persisted over the six to ten subsequent years of observation. Life circumstances, and the resulting average

\footnotetext{
${ }^{2}$ Although Ivlevs (2015) later attempts to show a monotonic increasing selection effect of life satisfaction on the desire to emigrate, this second result hinges critically on the validity of an unusual instrument, having a parent or grandparent who was injured or killed in the second world war, which would likely follow an unusual age distribution and indeed interfered markedly with the coefficients on the age dummies in their second-stage results.
} 
life evaluation scores, differ ten times more among countries than within countries, even among the states of the United States or the provinces of Canada. Hence the move from one country to another is much more likely to involve changes in life circumstances large enough to trigger significant changes in life evaluations. Large changes in life satisfaction, of several points on a 10- or 11-point scale, sustained over time would provide a more convincing argument against the set point hypothesis.

Although panel data sets covering international migration are rarer still, results using these data sets have largely agreed with cross-sectional results. In a panel of Ingrian-Finnish migrants from Russia to Finland who were interviewed during Finnish language courses prior to their departure and were followed for up to three years, stable and significant increases in life satisfaction were recorded after migration (Lönnqvist et al., 2015). In a rare instance of a randomized trial, Stillman et al. (2015) were able to observe potential migrants from Tonga to New Zealand who were entered into an immigration lottery. Unfortunately, measures of global life satisfaction were not captured, although several domain satisfactions were recorded, along with reports of general happiness and mental health. Relative to the control group, those who migrated reported decreased happiness, but improved mental health. Lastly, in the largest panel study of international migration (to the extent that East and West Germany are considered separate countries) and life satisfaction to date, Melzer (2011) found that migrants from East to West Germany in the years after reunification experienced a permanent increase in life satisfaction following their move. Although it was observed that, consistent with the Easterlin paradox (Easterlin, 1974, 1995), the average life satisfaction of this group did not continue to rise with their ever-increasing average income, Melzer (2011) interpreted this to be a result of their relative incomes remaining low compared to those of West German natives.

Due in large part to data limitations, the studies listed above have tended to examine only a small number of source-destination pairs. The exceptionally large sample sizes available through Statistics Canada’s Canadian Community Health Surveys and General Social Surveys allowed Frank et al. (2016) to analyze the average difference in life satisfaction among Canadian immigrants from 43 different source countries. Remarkably, the differences between immigrants and the native born tended to be small and not statistically significant. When immigrants' life 
satisfaction was compared to the satisfaction of those who remained in their source countries, the gap was almost as large in each case as the gap between life satisfaction in Canada and in each of the source countries, even where the source-country averages were far less than those in Canada. Thus the difference in life circumstances appeared to explain almost the entire difference in the international averages, even after controlling for socioeconomic and demographic factors that might drive selection into immigration. It was seeing an early version of that research paper that led us to expand the sample and use migration data more directly as a test bed for the set point hypothesis.

\section{Data and Methods}

We first assemble comparable measures of subjective well-being for immigrants in Canada ${ }^{3}$, and for populations currently living in the source countries. Life evaluations in Canada and the source countries provide the basis for our test of the set point hypothesis. This choice is driven by several reasons.

First, we have comparable Canadian and source-country data for life evaluations, but not for measures of positive or negative affect.

Second, international differences in life evaluations have been shown to be much larger than for emotional reports, and hence more likely to be affected by migration. Of the global variations in individual life evaluations in the years 2010-2012, more than 25\% were across rather than within nations, compared to less than $10 \%$ for positive affect and $7 \%$ for negative affect (Helliwell and Wang, 2013, Figure 2.1).

Third, differences in life evaluations are more fully explained by differences in life circumstances than are differences in positive and negative emotions. For example, the World Happiness Report 2015 shows (in Table 2.1) that six variables reflecting key differences in life

\footnotetext{
${ }^{3}$ Due to the nature of questions regarding citizenship and immigrant status on the surveys used for this study, this sample includes, aside from immigrants (permanent residents of Canada), foreign-born temporary residents in Canada, and some foreign-born Canadian citizens by birth. For ease of exposition, we use the term "immigrant" throughout the paper to refer to this whole sample.
} 
circumstances explain $74 \%$ of the differences in national average life evaluations, compared to $49 \%$ for the corresponding differences in positive affect and $22 \%$ for negative affect.

Thus we are expecting that life evaluations will provide the most appropriate means for showing that subjective well-being can be permanently shifted by changes in life circumstances. But at the same time we recognize and expect that the set point hypothesis might well be a larger part of the story for some other measures of subjective well-being, including positive and negative affect. Our available data, which only include life evaluations, do not permit us to test this possibility.

We use two different sources for source-country life evaluations: life satisfaction answers (on a scale from 1 to 10) from the World Values Survey (WVS), and responses to the Cantril ladder question (on a scale from 0 to 10) from the Gallup World Poll (GWP).

The data for Canada are from two nationally representative household surveys: six waves of the General Social Survey (GSS) (2008 to 2011, 2013 and 2014) and six waves of the Canadian Community Health Survey (CCHS) (2009 to 2014). For the first stage of our study the data for the populations in immigrants' source countries are from Waves 3 to 5 of the WVS, conducted between 1994 and 2008.

The countries chosen for the first part of our analysis are those with more than 50 immigrants to Canada over the previous twenty years, and which have also been covered by the WVS. Compared to the earlier analysis by Frank et al. (2016), we have been able, thanks to the availability of several new survey rounds, to increase the robustness of the analysis by increasing from 20 to 50 the number of Canadian immigrants required for a source country to be included. The Frank et al. analysis covered 43 countries with more than 20 immigrants in the previous 10 years, and 58 with more than 20 immigrants in the previous 20 years. Our first-stage analysis covers 56 countries with more than 50 immigrants in the preceding 20 years. In our later analysis using the GWP to provide greater coverage of source-country data, we will be able to analyze 81 countries with more than 50 immigrants to Canada in the past 20 years, and 100 countries with more than 50 immigrants in the past 40 years. 
Table 1 provides an alphabetical list of all of the source countries appearing in either stage of analysis, along with the numbers of immigrants to Canada (where that number equals or exceeds 50), for both the 20 and 40-year immigration spans, and also the sizes of the WVS samples in each of the 56 first-stage source countries.

Our research methods are similar to those used by Frank et al. (2016). We compare average life satisfaction levels of immigrants to Canada to those in the countries from which they have emigrated. If the life satisfaction of all immigrants tends to approach that of other Canadians despite the large differences in subjective well-being among the various source countries, this would provide strong evidence that reported life satisfaction depends on the circumstances in the countries in which they live, rather than on the genetic mix and cultures of the countries in which they were born.

In the first stage of our analysis we shall test whether selection effects are likely to make the Canadian immigrant sample unrepresentative of the source populations. We certainly expect differences, especially in the case of immigrants coming under the Canadian immigration points system, as the system attaches a high value to higher education, and to language skills in English and French, with the result that the immigrant populations have university graduate proportions even higher than those found among the Canadian-born. To see whether these selection effects are likely to distort the average life satisfaction scores of the immigrant groups, we first pool the source-country and immigrant data and estimate, following Frank et al. (2016), an equation explaining individual satisfaction with life using a number of mainly demographic variables that are likely to be correlated with life satisfaction and which may also take different values for migrants and non-migrants in the source populations. The estimated equation is shown in Table 2.

$$
S W L_{i}=\sum_{k=1}^{56} \delta_{k} C_{k}^{I M}+\sum_{k=1}^{56} \lambda_{k} C_{k}^{S C}+X_{i} \beta+\tau S^{I M}+\epsilon_{i}
$$

The regression equation was estimated with a separate constant term for each of the 56 groups of immigrants $\left(\delta_{k}\right)$ and each of the 56 source-country samples $\left(\lambda_{k}\right)$. Individual characteristics, $X_{i}$, 
include a quadratic in age (the variable included in the regression was actually defined as age_reg = age -45), a gender dummy, a set of indicators of marital status (common-law, widowed, divorced/separated, single, with married as the reference group), a set of indicators of highest educational attainment (some post-secondary, high school, less than high school, with university degree as the reference group), a set of indicators of labour force status (unemployed, not in the labour force, with employed as the reference group), and self-assessed health status (the middle of five categories was chosen as the reference group). ${ }^{4}$ Finally, survey indicators $S^{I M}$ were included for the Canadian data sources since earlier research found systematic differences in life satisfaction levels between the GSS and CCHS surveys, and across the GSS cycles (Bonikowska et al., 2014). The estimated coefficients $\delta_{k}$ and $\lambda_{k}$ represent the average satisfaction with life among immigrants in Canada from a given source country and people living in the source countries for a reference person. This is a 45-year-old married employed male university graduate in the middle health category. The estimated coefficients can then be used to predict the satisfaction with life (SWL) of anyone with differing characteristics.

The GWP also includes a series of questions on international migration intentions, which allow us to check for signs of selection on unobservable characteristics. Each respondent in the GWP is asked whether, given the opportunity, they would like to move permanently to another country. Those who answer in the affirmative are also asked to name the country that they would most like to move to in that event. Starting in 2010, respondents were also asked whether they intended to move to that country within the next 12 months. While the large majority of individuals reported that they would prefer not to emigrate, approximately one in five indicated that they would do so given the chance. Of these, one in twenty (or approximately $1 \%$ of the overall sample) reported that they would most like to move to Canada. Another one in ten of these (approximately $0.1 \%$ of the overall sample) indicated an intention to move permanently to Canada in the next 12 months.

\footnotetext{
${ }^{4}$ Five categories of answers were available in both the Canadian surveys and the WVS. In Canada, the five categories are labelled: excellent, very good, good, fair and poor. In the WVS the labels are: very good, good, fair, poor and very poor. In several countries, no responses were recorded under "very poor".
} 
Figure 1 presents the average levels of subjective well-being, measured by the Cantril ladder, for each of these groups by region. ${ }^{5,6}$ Not surprisingly, those who would like to emigrate score significantly lower than those who would prefer to stay. Even the highly selected sub-sample who want to move to Canada in particular score either significantly lower than the rest of the population, or no better. Meanwhile, as we move from left to right within each region of origin in Figure 1 the samples are becoming more similar to the actual immigrants sampled in the CCHS and GSS. In all regions the proportion of individuals aged 22 or over who have completed a fouryear university degree rises substantially, from approximately $10 \%$ globally, to $14.5 \%$ among those willing to move in general, up to $22.5 \%$ for those who want to move to Canada. Although recent immigrants in Canada are more likely still to have completed a university degree, even restricting the analysis to those who have completed at least four years of post-secondary education does not qualitatively change the results in Figure 1. Although potential emigrants to Canada are better educated on average, they do not appear to be systematically happier than their counterparts who would rather stay in the home country.

Return migration could also be a source of selection bias. Not everyone who immigrates to Canada decides to stay, and the chronically dissatisfied may decide to return to their home countries or emigrate elsewhere. Since we only observe those who haven't left, this could skew the distribution of life satisfaction within our sample of immigrants in Canada. Although exact figures are not available, analysis based on census and tax records suggests that the return migration rate for immigrants in Canada is on the order of 1\% per year during the first ten years after arrival (Aydemir and Robinson, 2006; Finnie, 2006). These data sets also imply a large turnover in the first year, possibly as high as one in five. However, these high turnover rates are based on comparisons between administrative data and landing records, and the extent to which this result may be due to imperfect linkages between the two data sources has not been

\footnotetext{
${ }^{5}$ For each region in Figure 1, the first three columns on the left use data from the GWP 2006 to 2015, while the remaining two columns use data starting from 2010, when the 12-month emigration intentions questions were added to the GWP, to 2015. Restricting the former to match the 2010-2015 collection period did not qualitatively change the levels. As a result, the broader range was maintained for these columns in order to increase precision.

${ }^{6}$ Data were used from all countries where the questions were asked, with national averages weighted by population to form the regional averages.
} 
established. ${ }^{7}$ Similarly to these other data sets, our sample from the GSS and CCHS does not directly show a sharp drop in the first year. Consequently, it is not clear to what extent these ultra-short-term immigrants are captured in our sample. The return migration that takes place during the subsequent two decades, however, is of a similar aggregate proportion, and any effects of selection out on the basis of set points should be clearly visible in our Figure 2.

Figure 2 depicts the time path of mean life satisfaction reported by immigrants in our sample by years since arrival. Under the low set point selection hypothesis, we should observe a steady increase in average life satisfaction as those at the bottom of the distribution of set points select out over time. Contrary to this, however, the time path of average life satisfaction is uniformly trendless over the first 20 years. This picture is not inconsistent with results in Figure 1 in which potential emigrants in North America and Europe tended to score significantly lower on the Cantril ladder than those who would prefer to stay, so long as these differences are driven by changing life circumstances, rather than low set points.

\section{Results}

Figures 3 and 4 plot the average life satisfaction of immigrants from each of the 56 first-stage countries against the WVS averages for the source countries. Each figure also shows a 45-degree line on which the points would be expected to fall if the satisfaction with life (SWL) of the migrants was unaffected by moving to Canada and if the migrants were randomly drawn from the sampled source populations. ${ }^{8}$ Figure 3 makes no adjustment for selection effects, effectively assuming that the immigrants are a random sample of the source-country population. Figure 4 plots the adjusted (for differences in socio-demographic characteristics) values using the equation of Table 2 (model 4) to estimate what the life satisfaction levels would be for someone with the assumed baseline characteristics in both the source-country and immigrant samples.

\footnotetext{
${ }^{7}$ Aydemir and Robinson (2006) note that $10-15 \%$ of immigrants never appear in their tax filing data. Consequently, the first year hazard rate observed within the tax data itself is less than half as high as that implied by the comparison to landing records.

${ }^{8}$ Another requirement for the points to fall on the 45-degree line is that the survey content does not differ substantially between the WVS and the Canadian surveys used in this study. The WVS was conducted in Canada in 2000 and again in 2006. In both years, the average measured SWL for Canada was approximately 7.8, about 0.2 points lower than the estimate obtained from the pooled GSS and CCHS samples (and controlling for survey and survey cycle), a difference far smaller than most gaps in average SWL between immigrants and their source-country populations.
} 
What is remarkable about the comparison between the two figures is how similar they are. Although it is indeed true that immigrants to Canada from some countries differ considerably, especially in age and education, from typical residents of their source-country population, adjusting for the effects these differences make to predicted SWL makes little difference either to the country rankings or to the slope of the plot of immigrant SWL relative to source-country SWL. The near-flatness of the distribution provides strong counter-evidence to the set point hypothesis, since that hypothesis requires that the immigrant SWL observations would instead lie along the 45-degree line. This should especially be the case for Figure 4, which adjusts for likely selection effects, at least to the extent that they are captured by the main demographic variables. Instead, in both figures the average immigrant life satisfaction is very close to that of other Canadians, whether the comparison is based on simple averages, as in Figure 3, or using scores adjusted for differences in characteristics of the immigrants and the source-country populations.

Figure 5 shows the extent of well-being convergence in a different way, for the same 56-country sample shown in Figures 3 and 4. The first three bars show the cross-country averages for the measured, predicted (using Equation 2) and adjusted SWL, respectively. The vertical lines for the confidence regions show that the three averages are within the same confidence region. The fourth and fifth bars show the averages for the immigrants to Canada from those same 56 countries. The fourth bar shows the average of immigrants who have been in Canada for 0 to 20 years, while the fifth bar shows the average for those in Canada from 0 to 40 years. The two averages are essentially identical, and the tight confidence intervals of the estimates show how great the convergence has been. In both cases average immigrant SWL is more than a full point, on the 10-point scale, above that in the source countries, with the average gains being much greater for those coming from countries with lower average SWL, showing once again the permanent effects of differences in life circumstances. Where the improvement in life circumstances has been greatest, as measured, for example, by the six key variables used in Helliwell, Huang and Wang (2015, Table 2.1) to account for differences among countries in life evaluations, then so has been the increase in the average life evaluations of the immigrants.

Because the adjustment for selection effects makes so little difference to the results, we were able to turn with more confidence to consider a larger set of countries for which the GWP 
provided data, with the average sample sizes also being larger. Figure 6 shows the data for the 81 countries that have more than 50 immigrants, in the survey samples, who have arrived in Canada in the last 20 years, while Figure 7 shows the relation for immigrants from the 100 countries with more than 50 sampled immigrants who have arrived in the previous 40 years. The numbers of sampled immigrants shown in Table 1 provide a good idea of the relative importance of different source countries, and how this importance has changed over the past 40 years.

The use of the GWP data to measure the SWL of the source countries poses an additional complication. The GWP asked the satisfaction with life question, on the same 0 to 10 scale used in the recent Canadian surveys, during only one year. In all years the main life evaluation question used is the one known as the Cantril ladder, which asks respondents to think of their lives as a ladder, with the best possible life for them as a 10, and the worst as a zero, and then to use this scale to rate their own current lives. It was very valuable to have at least one year in which both questions were asked, as this enabled some key results to be discovered. One is that while the distributions of the answers to the two questions differed, when asked of the same respondents, the answers were explained by the same underlying factors, with very similar coefficients, so much so that the overall equation obtained a better fit if the two answers were averaged (Helliwell et al., 2010). Second, we are able to model the differences between the means of the two distributions so as to be able to convert the average ladder scores to a predicted average life satisfaction score for each country. Looking across countries, the life satisfaction scores are on average higher than those for the Cantril ladder, especially for those countries with higher average ladder scores, as shown by the following equation:

$$
\widehat{S W L}=-0.37+1.16 * \text { Cantril ladder }
$$

Figures 3, 4, 6 and 7 all show a clear convergence pattern that seems to apply to all source countries. Immigrants from Latin America show as having higher life satisfaction than those from other regions, while those from East Asia are less so. This parallels a similar finding from the global modeling of life evaluations, in which a common model shows positive residuals in Latin America and negative ones in East Asia (Helliwell, Huang, and Wang, 2015, p. 29). 
Figure 8 shows the extent of well-being convergence in a different way for the largest 100-country sample shown in Figure 7. There are three bars in Figure 8, each with a vertical line showing the 95\% confidence range for the estimates. The first bar shows the average Cantrilladder life evaluation in the 100 source countries, while the second shows the average estimated SWL measures in the same 100 countries, where each country's average is computed using Equation 2, reflecting the fact that, although SWL and the Gallup ladder are determined by the same factors, SWL increases more than does the Gallup ladder as subjective well-being increases. It is the data shown in the second bar that are plotted in Figure 7 against the average SWL of immigrants to Canada from those same countries. The right-hand bar of Figure 8 shows the average SWL of immigrants from the 100 countries, while the short vertical error bar provides an estimate of the 95\% confidence region for the average. Two things are immediately apparent when bars 2 and 3 of Figure 8 are compared. First is that the average SWL of the immigrants is far higher than that of the residents of the source countries. Second, and perhaps even more telling as evidence against the set point, is how great the extent of convergence is. The tight confidence region in the right-hand bar is another way of documenting the flatness already apparent in Figure 7.

Finally, the panels of Figure 9 compare, for each of nine source regions for immigrants to Canada, the distribution of SWL answers of immigrants compared to the distribution of sourcecountry SWL in the WVS in those same regions. Once again, the effects of convergence are apparent. Although there are marked differences in the shapes, and not just the averages, of the distributions of SWL in the source regions, the distribution shapes for the migrants are remarkably similar across Canadian immigrant groups. All immigrants are not equally satisfied with their lives, but the shape of the distribution tends to mimic that of other Canadians over the same period of time, as shown in Figure 10, rather than that in the global regions in which they were born. We reject the null hypothesis of equality of distributions of satisfaction with life among immigrants in Canada and distributions in their source regions at conventional significance levels using the Epps-Singleton test. ${ }^{9}$ Because of the large sample sizes, we also reject the null hypothesis of equality of distributions in most pair-wise tests comparing

\footnotetext{
${ }^{9}$ We use the Epps-Singleton test (Epps and Singleton, 1986) rather than the more common KolmogorovSmirnov test because the latter requires that the distributions tested be continuous, whereas the former allows both continuous and discrete distributions, with the life satisfaction evaluations being of the latter type (Goerg and Kaiser, 2009).
} 
immigrants from different regions to one another, and to the Canadian-born. However, the life satisfaction evaluations among immigrants, unlike in most source regions examined, but similarly to the Canadian-born, are concentrated at values 7 and higher, with fewer than $10 \%$ reporting values of 5 or 6 , and almost no reported evaluations lower than 5 . For immigrants from all regions, the average gap between their life satisfaction and the average in their source populations is several times greater than between them and those born in Canada. The same is true for the inequality of life satisfaction, as measured by the standard deviation of life evaluations within each group.

\section{Discussion}

The flatness of the distributions in Figures 3, 4, 6 and 7 shows not just that immigrants to Canada are happier on average than those in their countries of birth, but that the improvement is much larger for those who immigrated from countries with lower average life satisfaction. Since international differences in average life evaluations are well-explained by differences in life circumstances, this implies that immigrants from the lower SWL countries have had bigger changes in their life circumstances, thus giving rise to greater migration-induced improvements in their life satisfaction.

The fact that immigrants have quite different gains or losses in average SWL, coupled with the evidence that the international differences in source-country SWL are largely explained by the same life circumstances and living conditions and social contexts that explain within-country differences in SWL, provides strong evidence that large changes in life circumstances are causing large permanent changes in life evaluations.

Although the distributions are flat, there is still a small but significant footprint effect, with those coming from lower SWL countries having a residual effect reflecting the circumstances into which they were born. This is consistent with the previously established footprint effects for some social norms, including trust and generosity, which help to support SWL at the individual and national levels. 


\section{References}

Aydemir, A., and C. Robinson. (2006). "Return and Onward Migration among Working Age Men". Analytical Studies Branch Research Paper Series, no. 273. Statistics Canada Catalogue no. 11F0019M. Ottawa: Statistics Canada.

Bartram, D. (2011). "Economic Migration and Happiness: Comparing Immigrants' and Natives' Happiness Gains From Income." Social Indicators Research 103(1): 57-76. doi:10.1007/s11205-010-9696-2

Bartram, D. (2015). "Inverting the Logic of Economic Migration: Happiness Among Migrants Moving from Wealthier to Poorer Countries in Europe." Journal of Happiness Studies 16(5): 1211-1230. doi:10.1007/s10902-014-9554-z

Brickman, P., D. Coates, and R. Janoff-Bulman. (1978). "Lottery Winners and Accident Victims: Is Happiness Relative?" Journal of Personality and Social Psychology 36(8): 917-927. doi:10.1037/0022-3514.36.8.917

Bonikowska, A., J.F. Helliwell, F. Hou, and G. Schellenberg. (2014). "An Assessment of Life Satisfaction Responses on Recent Statistics Canada Surveys." Social Indicators Research 118(2): 617-643.

Brickman, P.D., and D.T. Campbell. (1971). "Hedonic Relativism and Planning the Good Society." In Adaptation-level Theory: A Symposium., ed. M. H. Appley, p. 287-302. New York: Academic Press.

Christoph, B. (2010). "The Relation Between Life Satisfaction and the Material Situation: A ReEvaluation Using Alternative Measures." Social Indicators Research 98(3): 475-499. doi:10.1007/s11205-009-9552-4

De Jong, G.F., A. Chamratrithirong, and Q.-G. Tran. (2002). "For Better, for Worse: Life Satisfaction Consequences of Migration." The International Migration Review 36(3): 838863. doi:10.1111/j.1747-7379.2002.tb00106.x

De Vroome, T., and M. Hooghe. (2014). "Life Satisfaction among Ethnic Minorities in the Netherlands: Immigration Experience or Adverse Living Conditions?" Journal of Happiness Studies 15(6): 1389-1406. doi:10.1007/s10902-013-9483-2

Diener, E., E.M. Suh, R.E. Lucas, and H.L. Smith. (1999). "Subjective Well-Being: Three Decades of Progress." Psychological Bulletin 125(2): 276-302. doi:10.1037/00332909.125.2.276

Dinesen, P.T. (2012). "Does Generalized (Dis)Trust Travel? Examining the Impact of Cultural Heritage and Destination-Country Environment on Trust of Immigrants." Political Psychology 33(4): 495-511. doi:10.1111/j.1467-9221.2012.00886.x 
Easterlin, R.A. (1974). "Does Economic Growth Improve the Human Lot? Some Empirical Evidence." In Nations and Households in Economic Growth, ed. P.A. David and M.W. Reder, p. 89-125. New York: Academic Press, Inc. Retrieved from http://graphics8.nytimes.com/images/2008/04/16/business/Easterlin1974.pdf

Easterlin, R.A. (1995). Will Raising the Incomes of All Increase the Happiness of All? Journal of Economic Behavior and Organization 27(1): 35-47. Retrieved from http://www.sciencedirect.com/science/article/pii/016726819500003B

Epps, T.W., and K.J. Singleton. 1986. “An Omnibus Test for the Two-Sample Problem Using the Empirical Characteristic Function.” Journal of Statistical Computation and Simulation 26(3-4): 177-203. doi:10.1080/00949658608810963

Finnie, R. (2006). "International Mobility: Patterns of Exit and Return of Canadians, 1982 to 2003." Analytical Studies Branch Research Paper Series, no. 288. Statistics Canada Catalogue no. 11F0019M. Ottawa: Statistics Canada.

Frank, K., F. Hou, and G. Schellenberg. (2016). "Life Satisfaction Among Recent Immigrants in Canada: Comparisons to Source-Country and Host-Country Populations." Journal of Happiness Studies 17(4): 1659-1680. doi:10.1007/s10902-015-9664-2

Fujita, F., and E. Diener. (2005). "Life Satisfaction Set Point: Stability and Change." Journal of Personality and Social Psychology 88(1): 158-164. doi:10.1037/0022-3514.88.1.158

Goerg, S.J., and J. Kaiser. (2009). "Nonparametric Testing of Distributions-the Epps-Singleton Two-Sample Test Using the Empirical Characteristic Function.” The Stata Journal 9(3): 454-465.

Grover, S., and J.F. Helliwell. (2014). "How's Life at Home? New Evidence on Marriage and the Set Point for Happiness." NBER Working Paper Series, no. 20794. Cambridge, Massachusetts: National Bureau of Economic Research.

Headey, B. (2008). "The Set-Point Theory of Well-Being: Negative Results and Consequent Revisions." Social Indicators Research 85(3): 389-403. doi:10.1007/s11205-007-9134-2

Headey, B., R. Muffels, and G.G. Wagner. (2013). "Choices Which Change Life Satisfaction: Similar Results for Australia, Britain and Germany." Social Indicators Research 112(3): 725-748. doi:10.1007/s11205-012-0079-8

Helliwell J.F., C.P. Barrington-Leigh, A. Harris, and H. Huang. (2010). "International Evidence on the Social Context of Well-Being." In International Differences in Well-Being, ed. E. Diener, J. F. Helliwell, and D. Kahneman, p. 291-327. New York: Oxford University Press.

Helliwell, J.F., H. Huang, and S. Wang. (2015). "The Geography of World Happiness." In World Happiness Report 2015, ed. J. F. Helliwell, R. Layard, and J. Sachs, chapter 2, p. 12-41. 
New York: Sustainable Development Solutions Network. Retrieved from http://worldhappiness.report/ed/2015/

Helliwell, J.F., and R.D. Putnam. (2004). "The Social Context of Well-Being." Philosophical Transactions of the Royal Society B: Biological Sciences 359(1449): 1435-1446. doi:10.1098/rstb.2004.1522

Helliwell, J.F., R. Layard, and J. Sachs (Eds.). (2015). World Happiness Report 2015. New York: Sustainable Development Solutions Network. Retrieved from http://worldhappiness.report/wp-content/uploads/sites/2/2015/04/WHR15_Sep15.pdf

Helliwell, J. F. and S. Wang. (2013). "World Happiness: Trends, Explanations and Distribution." In World Happiness Report 2013, ed. J.F. Helliwell, R. Layard, and J. Sachs, chapter 2, p. 8-37. New York: Sustainable Development Solutions Network. Retrieved from http://worldhappiness.report/ed/2013/

Helliwell, J.F., S. Wang, and J. Xu. (2016). "How Durable are Social Norms? Immigrant Trust and Generosity in 132 Countries." Social Indicators Research 128(1): 201-219. doi:10.1007/s11205-015-1026-2

Ivlevs, A. (2015). "Happy Moves? Assessing the Link between Life Satisfaction and Emigration Intentions." Kyklos 68(3): 335-356. doi:10.1111/kykl.12086

Lönnqvist, J.-E., S. Leikas, T.A. Mähönen, and I. Jasinskaja-Lahti. (2015). "The Mixed Blessings of Migration: Life Satisfaction and Self-Esteem over the Course of Migration." European Journal of Social Psychology 45(4): 496-514. doi:10.1002/ejsp.2105

Lucas, R.E. (2005). "Time Does Not Heal All Wounds: A Longitudinal Study of Reaction and Adaptation to Divorce." Psychological Science 16(12): 945-950. doi:10.1111/j.14679280.2005.01642.x

Lucas, R.E. (2007). "Adaptation and the Set-Point Model of Subjective Well-Being: Does Happiness Change after Major Life Events?" Current Directions in Psychological Science 16(2): 75-79. doi:10.1111/j.1467-8721.2007.00479.x

Lucas, R.E., A.E. Clark, Y. Georgellis, and E. Diener. (2004). "Unemployment Alters the Set Point for Life Satisfaction." Psychological Science 15(1): 8-13. doi:10.1111/j.09637214.2004.01501002.x

Luhmann, M., W. Hofmann, M. Eid, and R.E. Lucas. (2012). "Subjective Well-Being and Adaptation to Life Events: A Meta-Analysis." Journal of Personality and Social Psychology 102(3): 592-615. doi:10.1037/a0025948

Lykken, D., and A. Tellegen. (1996). "Happiness Is a Stochastic Phenomenon." Psychological Science 7(3): 186-189. doi:10.1111/j.1467-9280.1996.tb00355.x 
Melzer, S.M. (2011). "Does Migration Make You Happy? The Influence of Migration on Subjective Well-Being." Journal of Social Research and Policy 2(2): 73-92.

Melzer, S.M. and R.J. Muffels. (2012). "Migrant's Pursuit of Happiness: The Impact of Adaption, Social Comparison and Relative Deprivation; Evidence from a 'Natural' Experiment." SOEPpapers on Multidisciplinary Panel Data Research, no. 448. Berlin: German Socio-Economic Panel Study.

Nowok, B., M. van Ham, A.M. Findlay, and V. Gayle. (2013). "Does Migration Make You Happy? A Longitudinal Study of Internal Migration and Subjective Well-Being." Environment and Planning A 45(4): 986-1002. doi:10.1068/a45287

Olgiati, A., R. Calvo, and L. Berkman. (2013). "Are Migrants Going Up a Blind Alley? Economic Migration and Life Satisfaction around the World: Cross-National Evidence from Europe, North America and Australia." Social Indicators Research 114(2): 383-404. doi:10.1007/s11205-012-0151-4

Polgreen, L.A., and N.B. Simpson. (2011). "Happiness and International Migration." Journal of Happiness Studies 12(5): 819-840. doi:10.1007/s10902-010-9229-3

Rice, T.W., and J.L. Feldman. (1997). "Civic Culture and Democracy from Europe to America." The Journal of Politics 59(4): 1143-1172. doi:10.2307/2998596

Safi, M. (2010). "Immigrants’ Life Satisfaction in Europe: Between Assimilation and Discrimination." European Sociological Review 26(2): 159-176. doi:10.1093/esr/jcp013

Senik, C. (2014). "The French Unhappiness Puzzle: The Cultural Dimension of Happiness." Journal of Economic Behavior \& Organization 106: 379-401. doi:10.1016/j.jebo.2014.05.010

Switek, M. (2016). "Internal Migration and Life Satisfaction: Well-Being Paths of Young Adult Migrants." Social Indicators Research 125(1): 191-241. doi:10.1007/s11205-014-0829-x

Soroka, S., J.F. Helliwell, and R. Johnston. (2007). "Measuring and modelling interpersonal trust." In Social Capital, Diversity, and the Welfare State, ed. F. Kay and R. Johnston, p. 95132. Vancouver: UBC Press.

Stillman, S., J. Gibson, D. McKenzie, and H. Rohorua. (2015). "Miserable Migrants? Natural Experiment Evidence on International Migration and Objective and Subjective WellBeing." World Development 65: 79-93. doi:10.1016/j.worlddev.2013.07.003

Veenhoven, R. (1994). "Is Happiness a Trait? Tests of the Theory that a Better Society Does Not Make People Any Happier.” Social Indicators Research 32(2): 101-160. doi:10.1007/BF01078732 
Voicu, B., and M. Vasile. (2014). "Do 'Cultures of Life Satisfaction' Travel?" Current Sociology 62(1): 81-99. doi:10.1177/0011392113516651

Yap, S.C.Y., I. Anusic, and R.E. Lucas. (2012). "Does Personality Moderate Reaction and Adaptation to Major Life Events? Evidence from the British Household Panel Survey." Journal of Research in Personality 46(5): 477-488. doi:10.1016/j.jrp.2012.05.005 
Figure 1

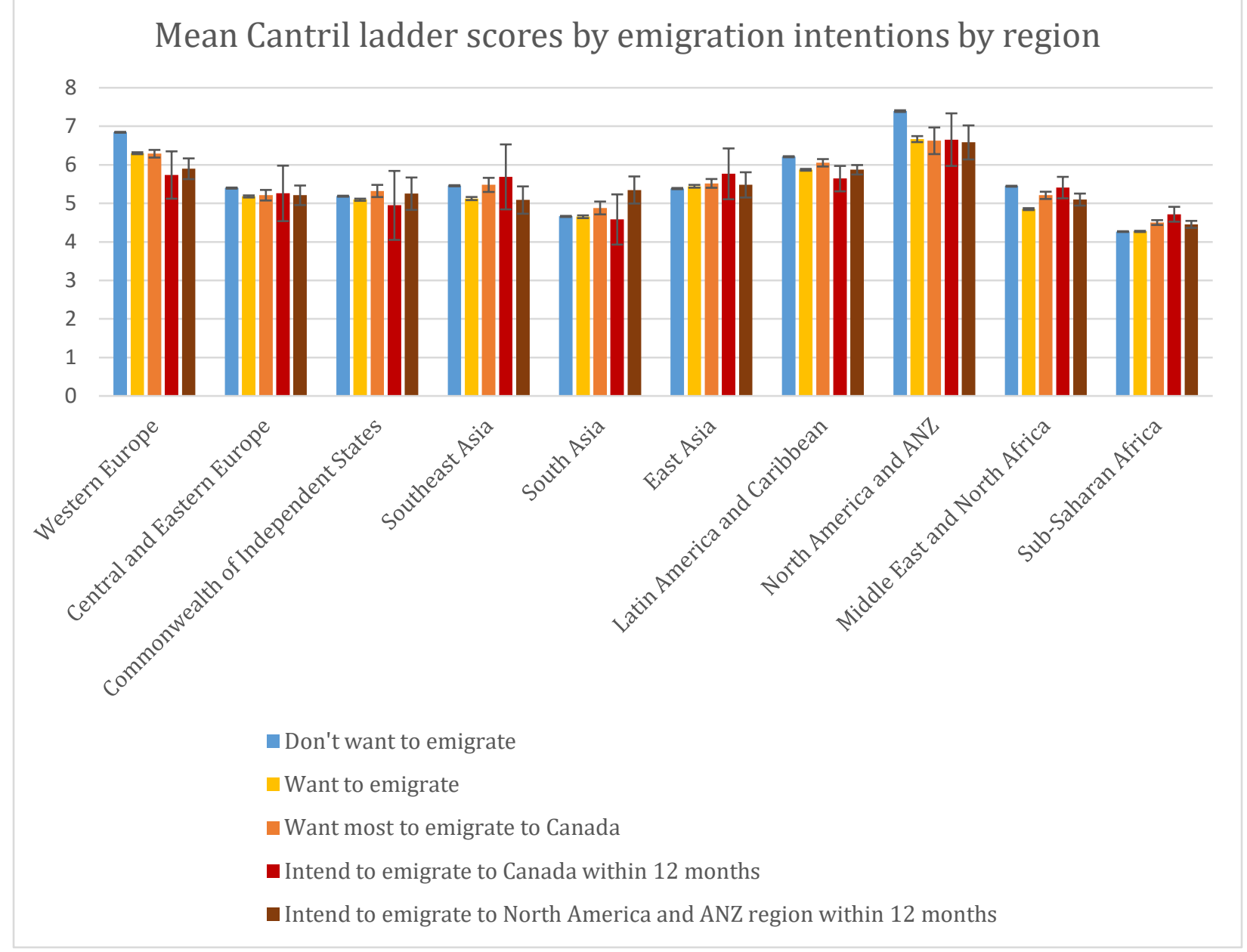


Figure 2

Observed satisfaction with life among immigrants in Canada from 49 countries by source region and years since arrival

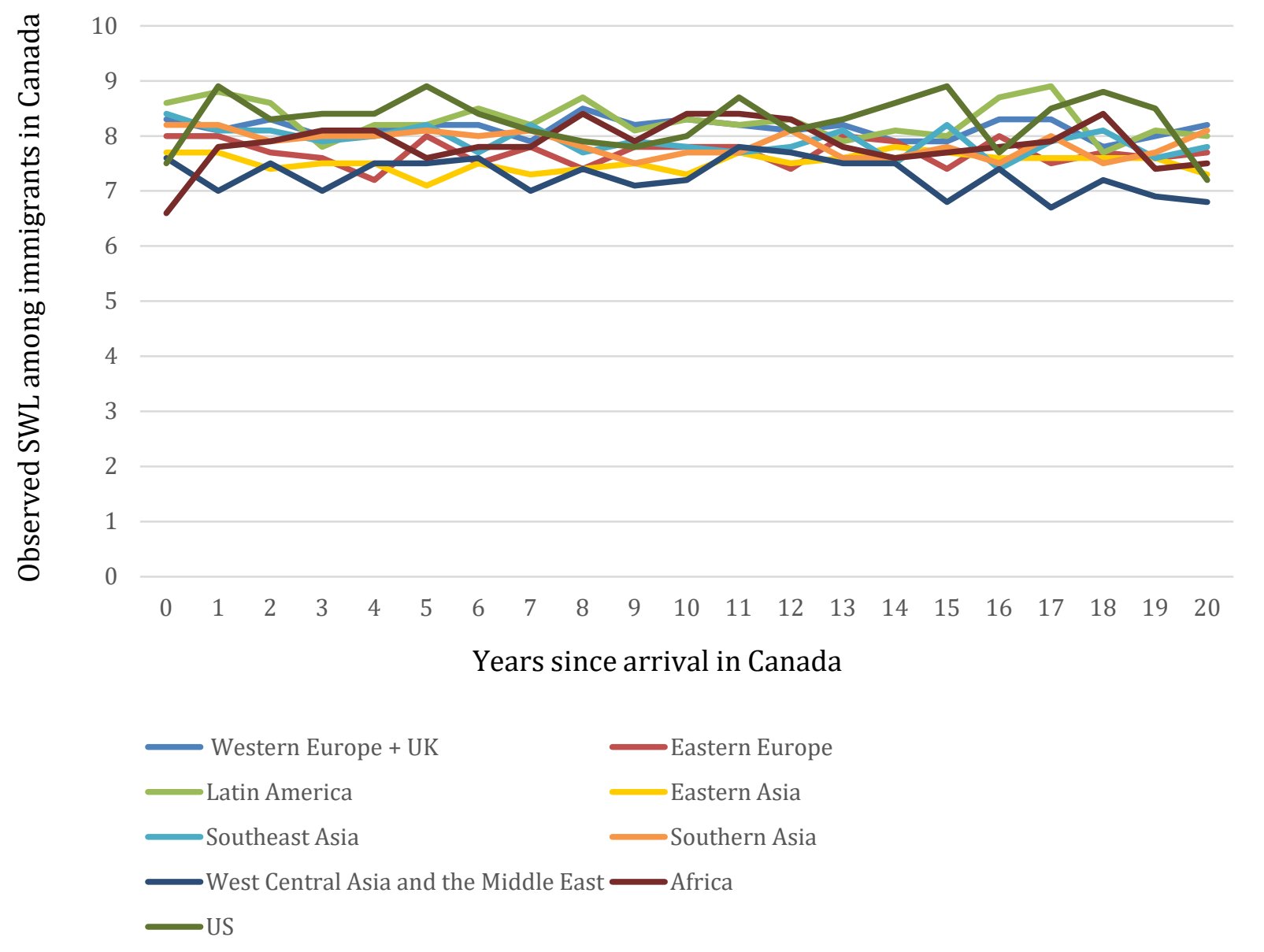

Note: Estimates adjusted for survey effects. 


\section{Figure 3}

Observed satisfaction with life among immigrants in Canada

( 0 to 20 years since arrival) from 56 countries and satisfaction with life in their source countries

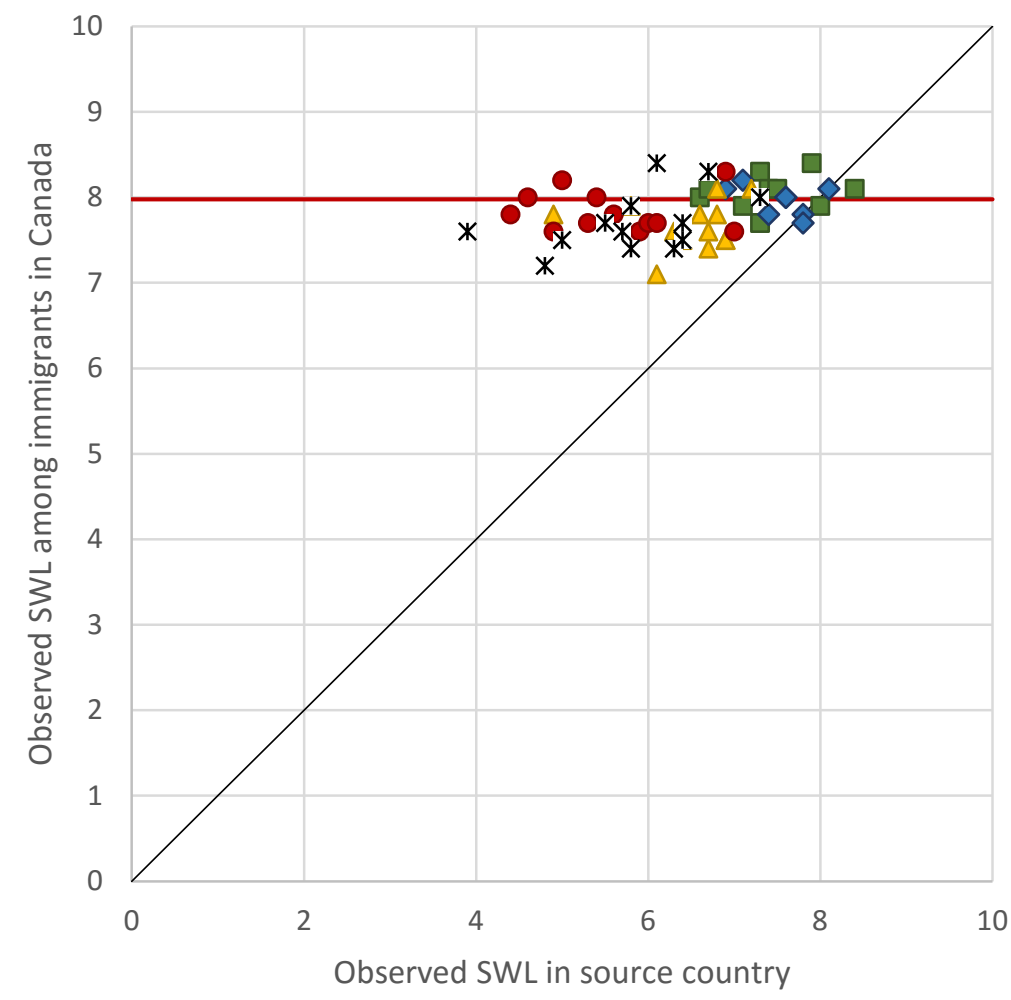

- Southcentral America and the Caribbean

$\diamond \quad$ North America, NW Europe and Oceania

$\triangle$ East and Southeast Asia

- Southeast Europe

* Africa, the Middle East and West Asia

-45-degree line

- Average life satisfaction in Canada

Note: Estimates based on Canadian data adjusted for survey effects. 


\section{Figure 4}

Adjusted satisfaction with life among immigrants in Canada

( 0 to 20 years since arrival) from 56 countries and satisfaction with life in their source countries

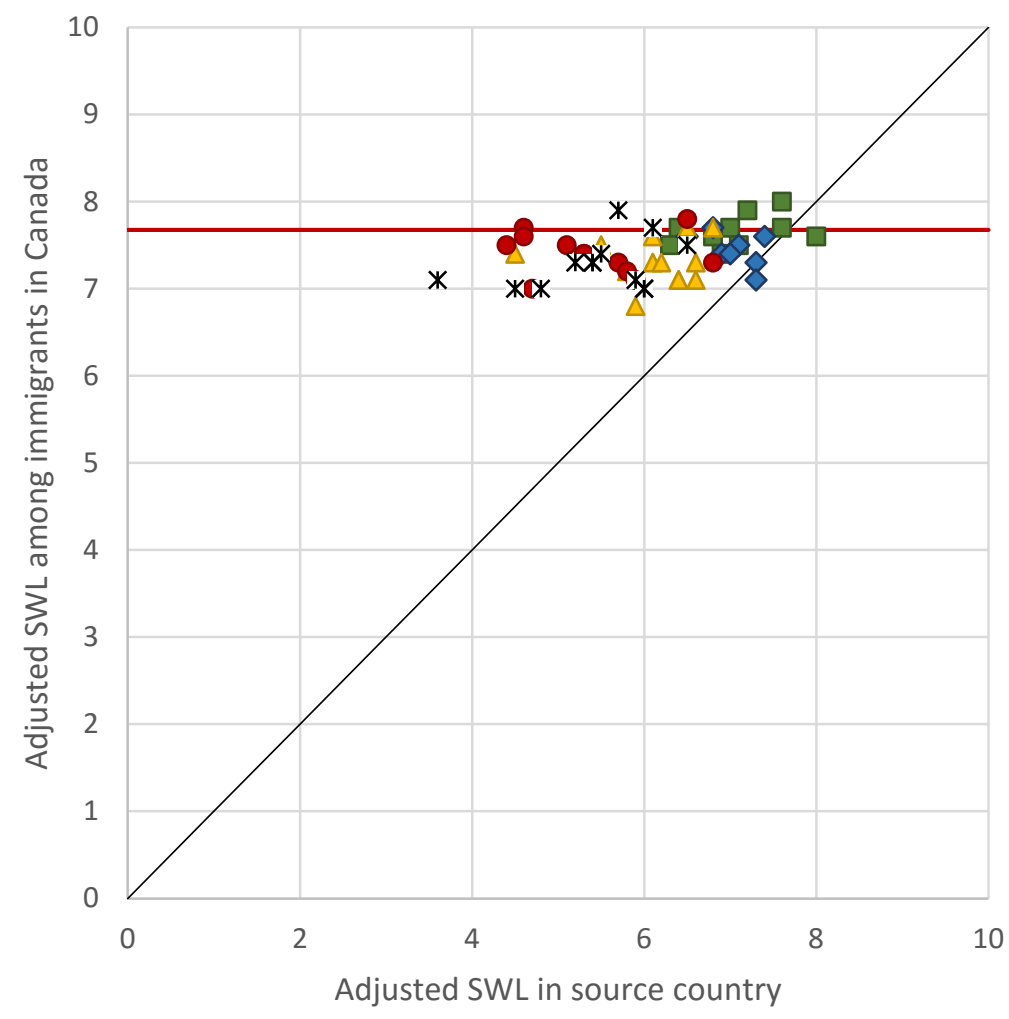

- Southcentral America and the Caribbean

$\diamond \quad$ North America, NW Europe and Oceania

$\Delta$ East and Southeast Asia

- Southeast Europe

* Africa, the Middle East and West Asia

-45-degree line

- Average life satisfaction in Canada

Note: Estimates based on Canadian data adjusted for survey effects. 
Figure 5

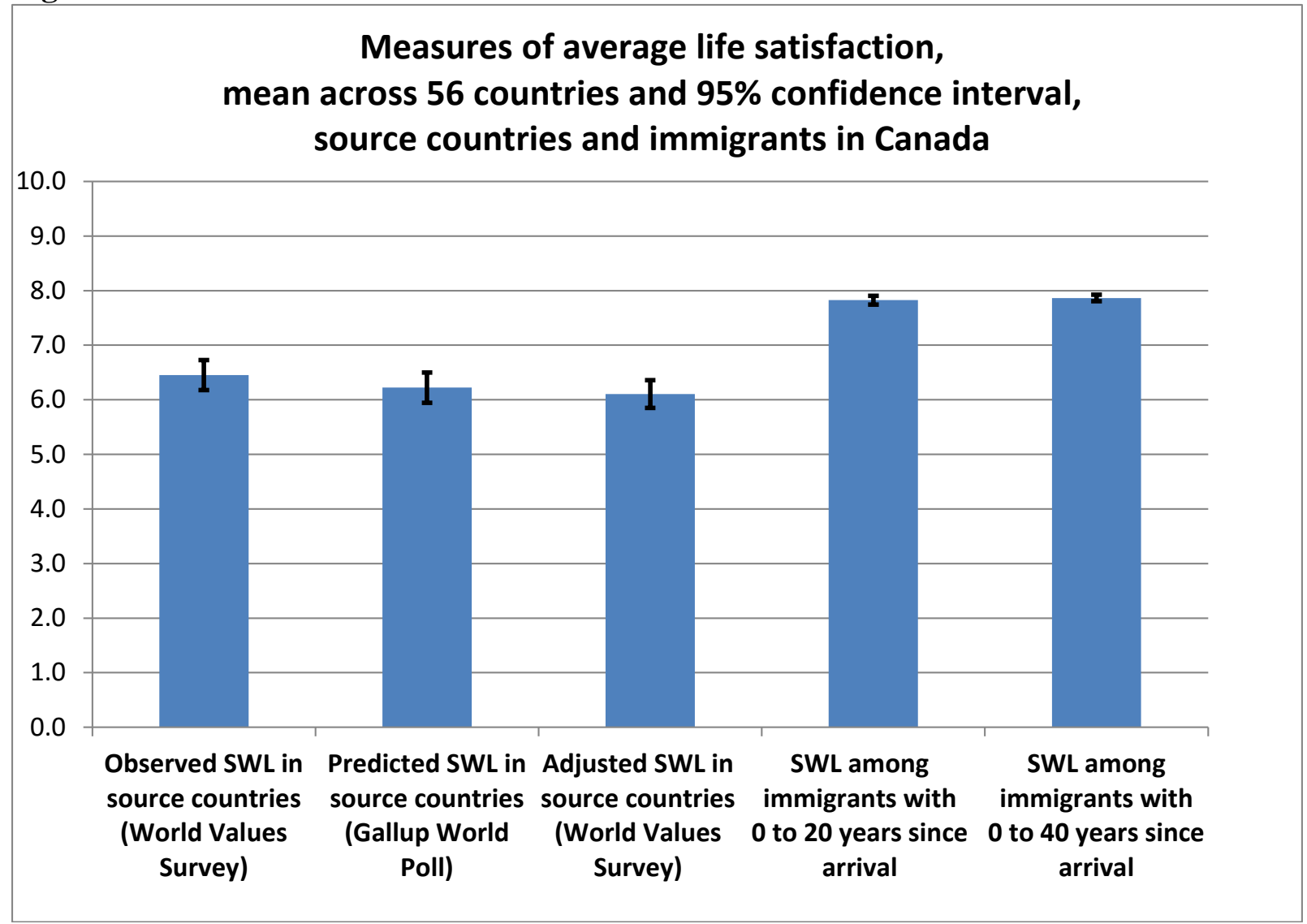

Note: Estimates based on Canadian data adjusted for survey effects. 


\section{Figure 6}

Observed satisfaction with life among immigrants in Canada ( 0 to 20 years since arrival) from 81 countries and predicted satisfaction with life in their source countries

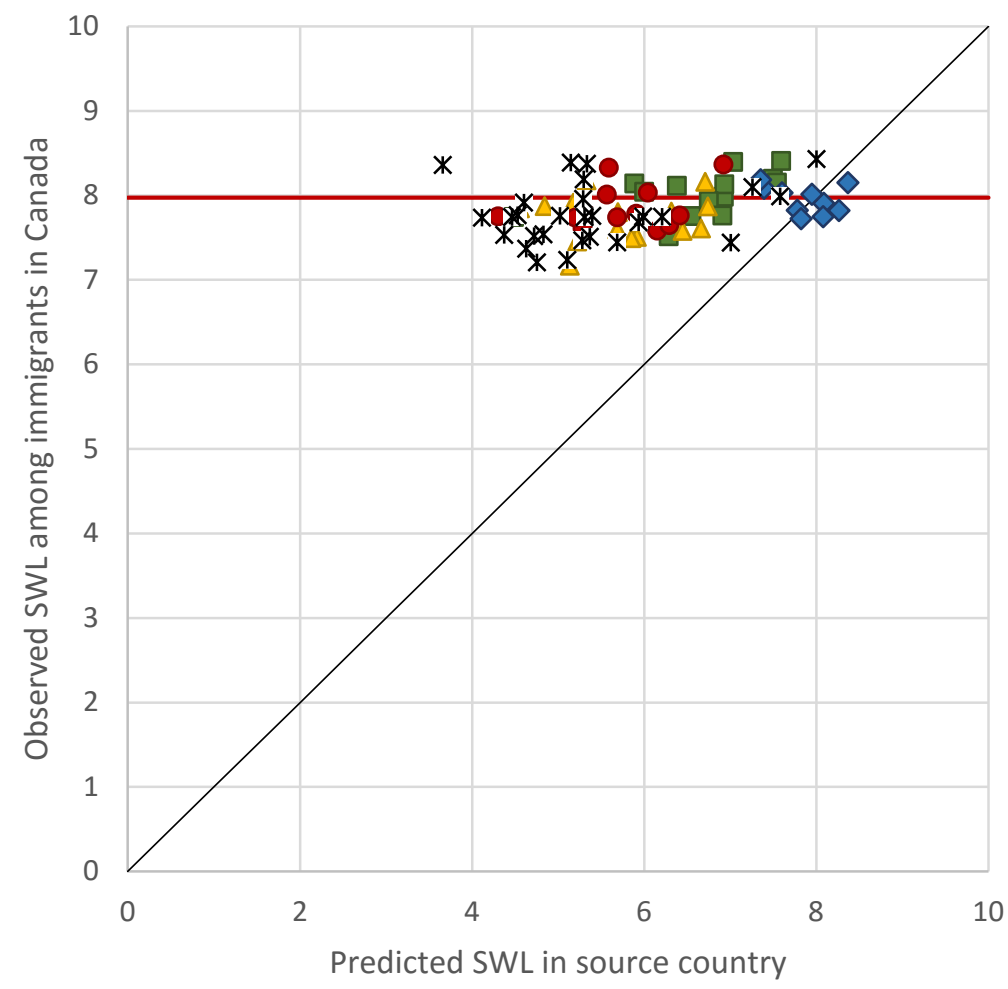

- Southcentral America and the Caribbean

$\diamond \quad$ North America, NW Europe and Oceania

$\Delta$ East and Southeast Asia

- Southeast Europe

* Africa, the Middle East and West Asia

-45-degree line

- Average life satisfaction in Canada

Note: Estimates based on Canadian data adjusted for survey effects. 


\section{Figure 7}

Observed satisfaction with life among immigrants in Canada ( 0 to 40 years since arrival) from 100 countries and predicted satisfaction with life in their source countries

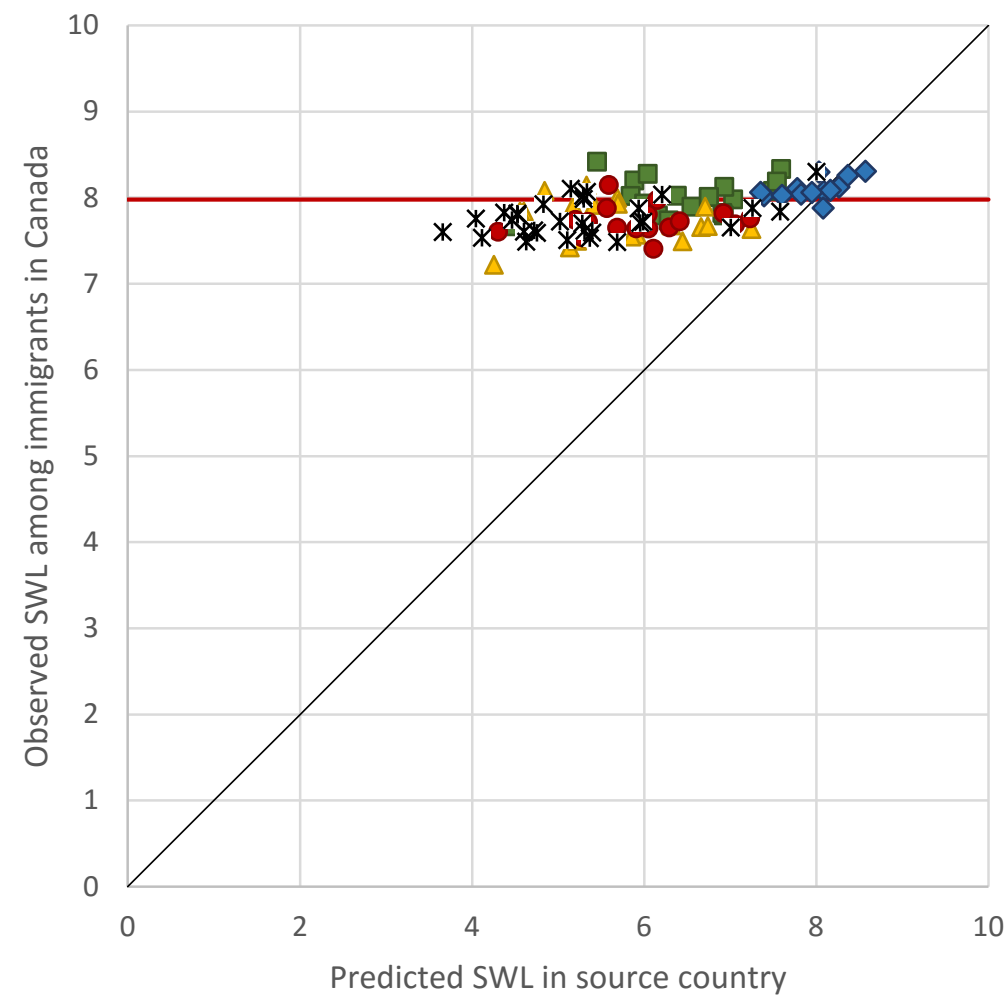

- Southcentral America and the Caribbean

$\diamond \quad$ North America, NW Europe and Oceania

$\Delta$ East and Southeast Asia

- Southeast Europe

* Africa, the Middle East and West Asia

_45-degree line

—_Average life satisfaction in Canada

Note: Estimates based on Canadian data adjusted for survey effects. 
Figure 8

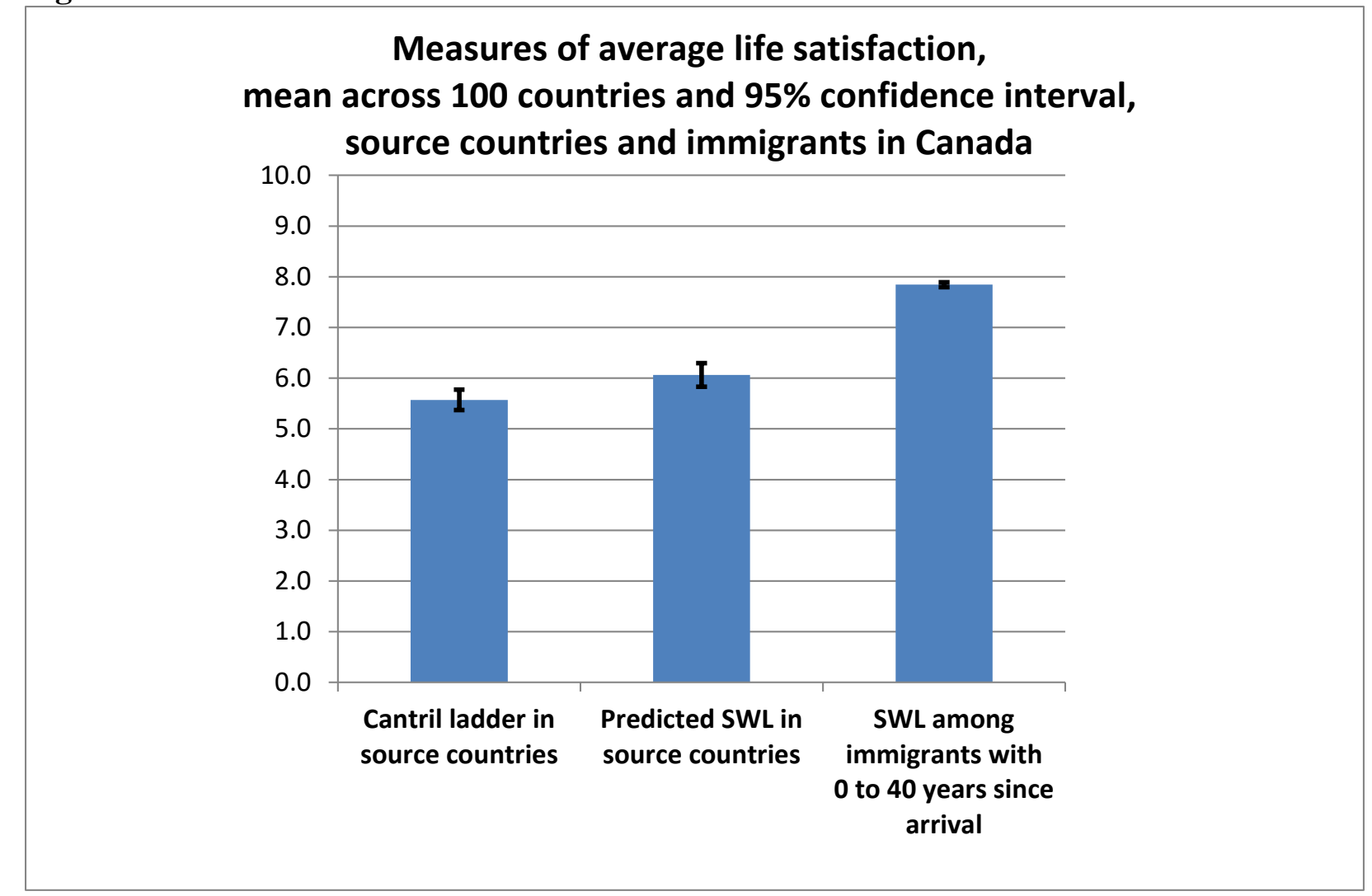

Note: Estimate based on Canadian data adjusted for survey effects. 
Figure 9

Distribution of satisfaction with life among immigrants in Canada (0 to 20 years since arrival) and source-country populations, by region
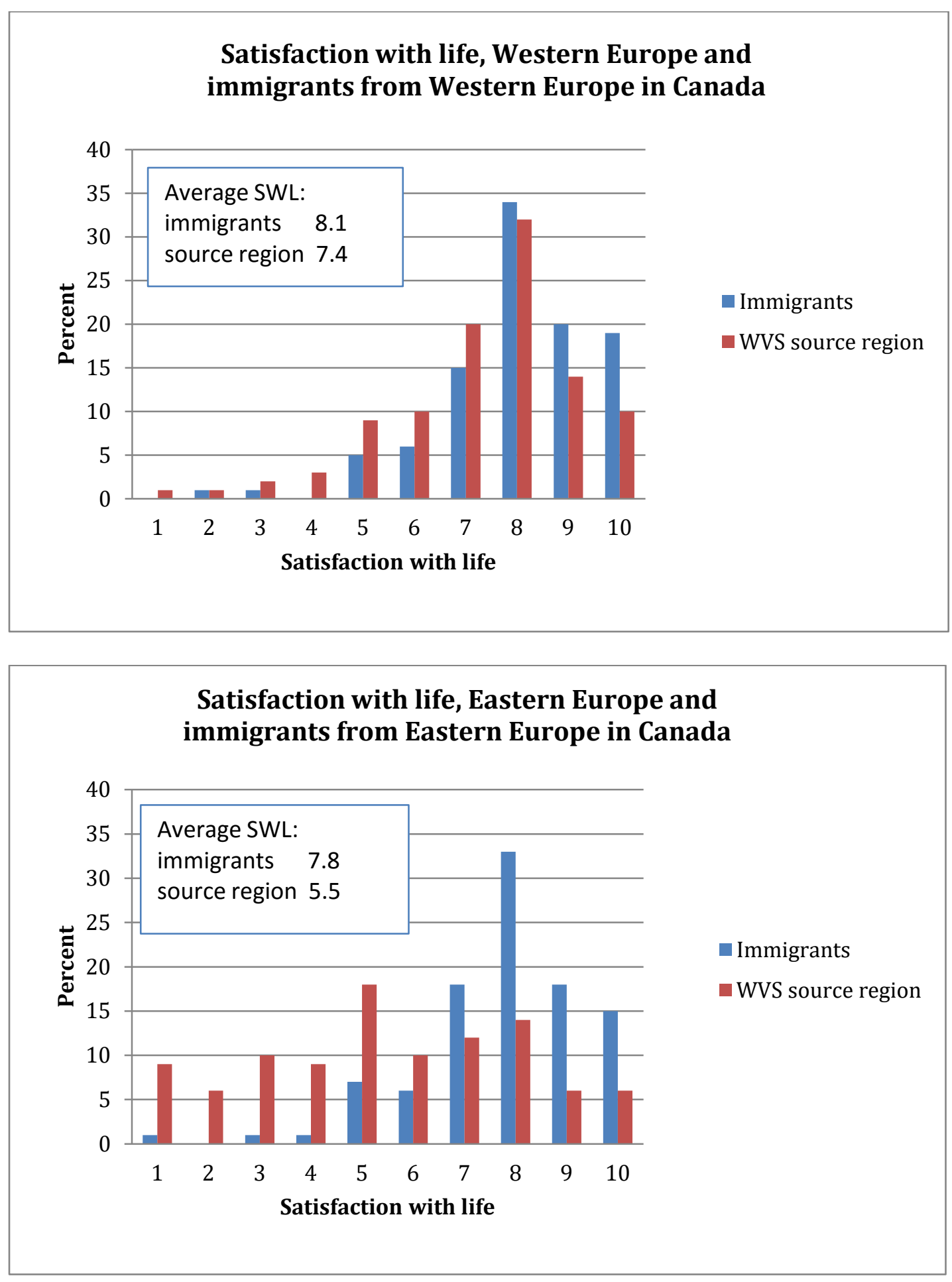

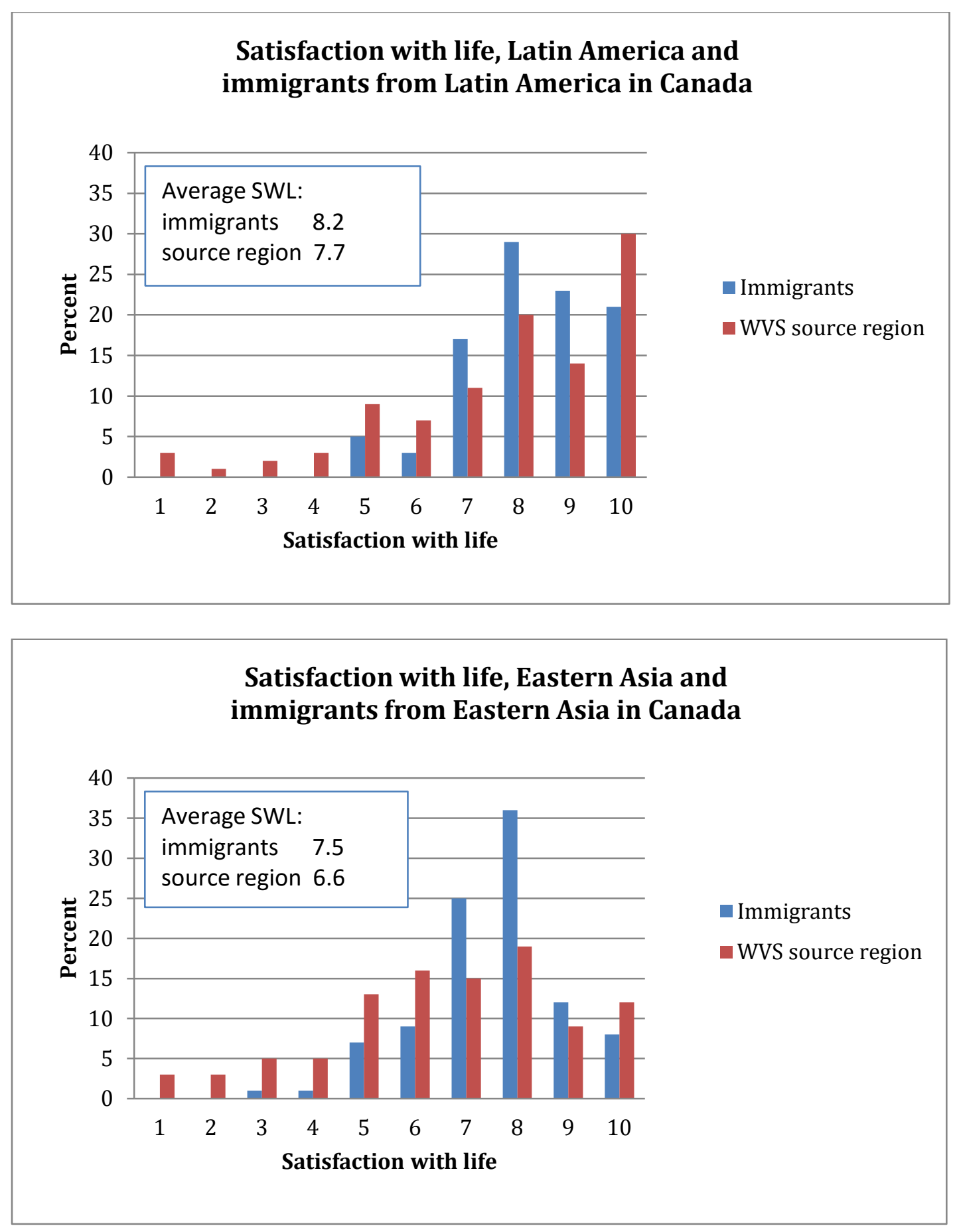

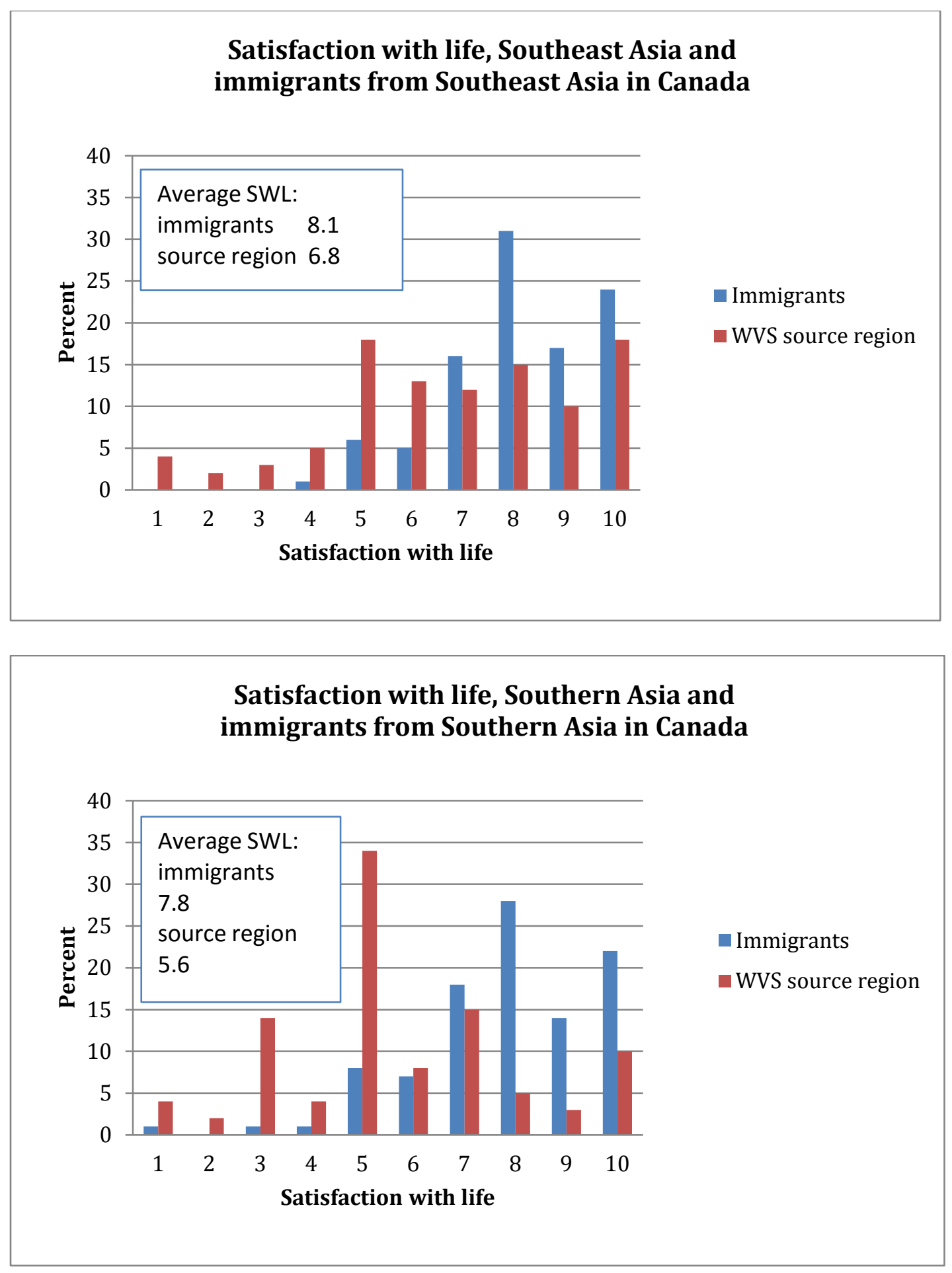

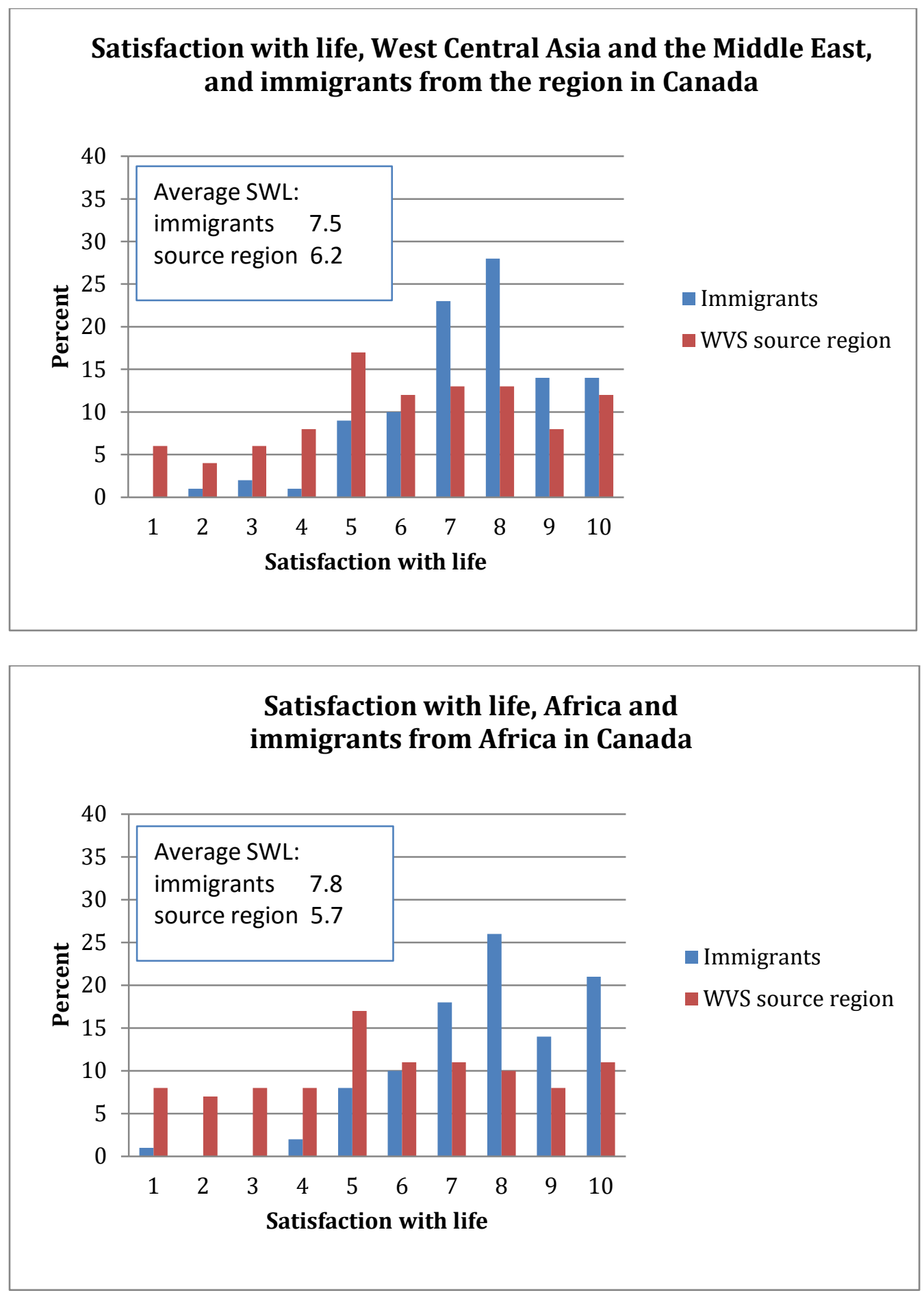


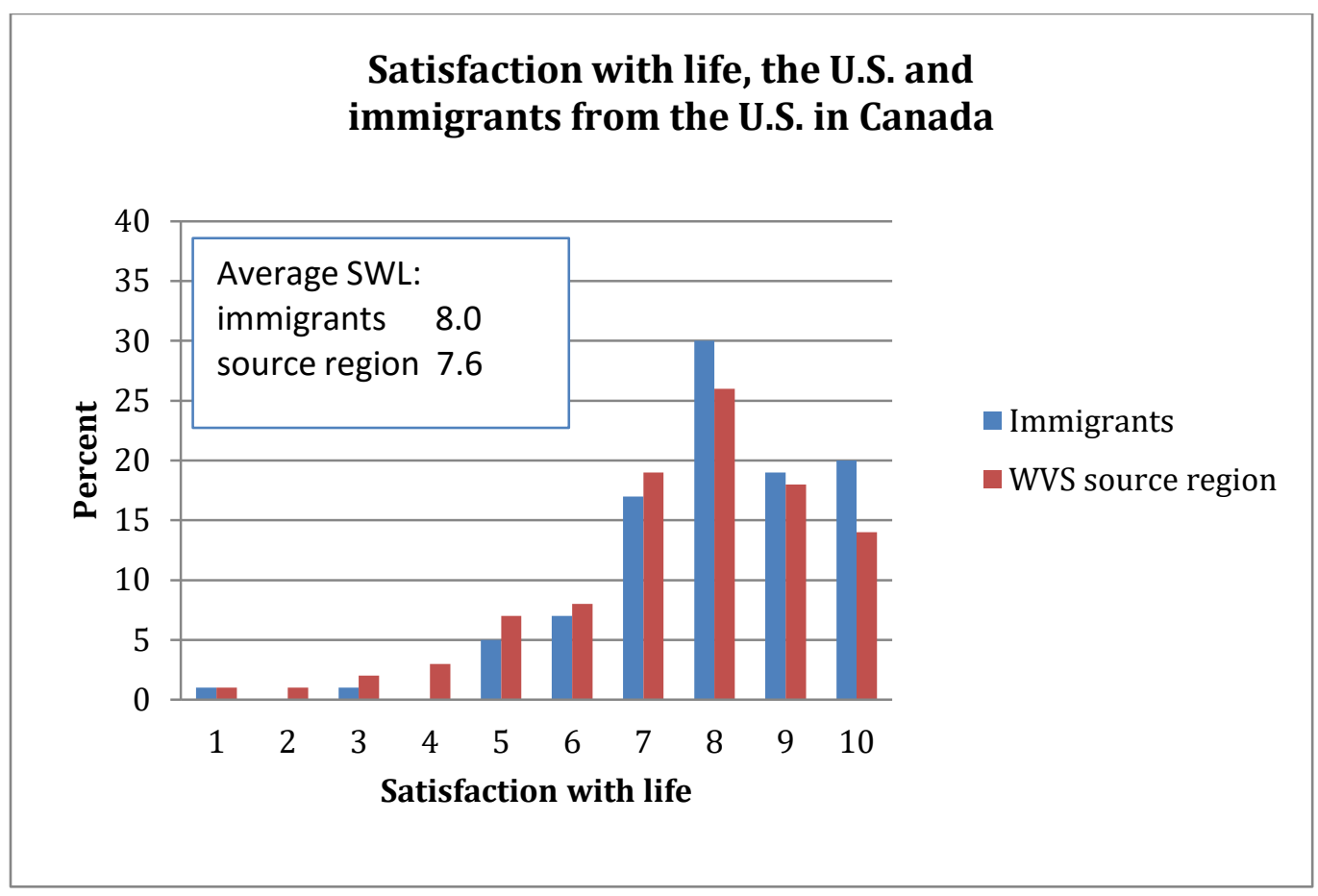


Figure 10

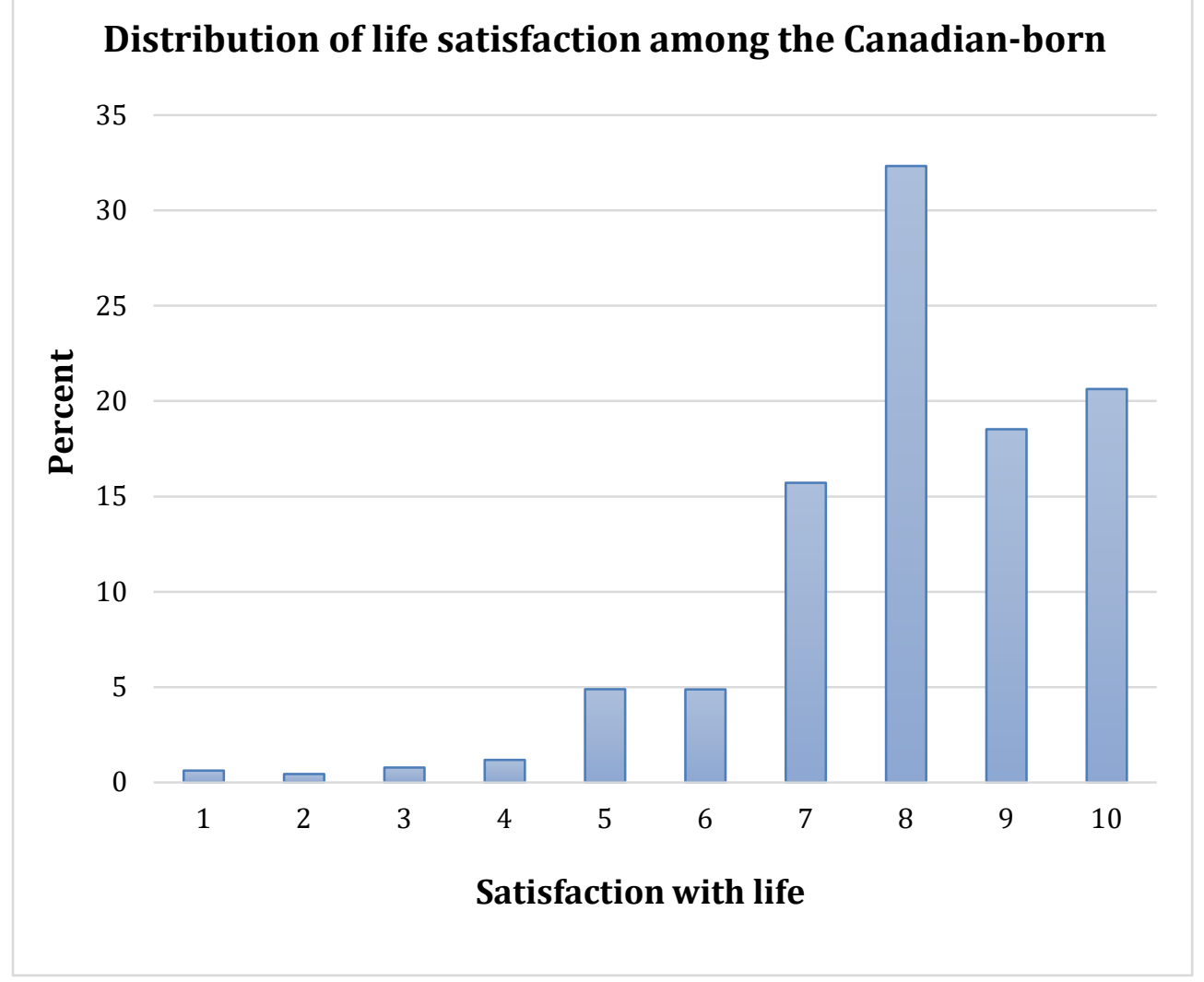


Table 1

Source countries included in analysis and sample sizes

\begin{tabular}{|c|c|c|c|c|c|}
\hline Source country & $\begin{array}{l}\text { Sample of } \\
\text { immigrants in } \\
\text { Canada, } 20 \text { or } \\
\text { fewer years } \\
\text { since arrival }^{\text {a }}\end{array}$ & $\begin{array}{l}\text { Sample of } \\
\text { immigrants in } \\
\text { Canada, } 40 \text { or } \\
\text { fewer years } \\
\text { since arrival }^{\mathrm{a}}\end{array}$ & $\begin{array}{l}\text { Source country } \\
\text { sample (World } \\
\text { Values Survey) }\end{array}$ & $\begin{array}{l}\text { Estimated } \\
\text { number of } \\
\text { immigrants } \\
\text { ( } 20 \text { or fewer } \\
\text { years since } \\
\text { landing) and } \\
\text { non- } \\
\text { permanent } \\
\text { residents in } \\
\text { Canada }^{c} \\
\end{array}$ & $\begin{array}{l}\text { Estimated } \\
\text { number of } \\
\text { immigrants } \\
\text { (40 or fewer } \\
\text { years since } \\
\text { landing) and } \\
\text { non- } \\
\text { permanent } \\
\text { residents in } \\
\text { Canada }^{c} \\
\end{array}$ \\
\hline & $(1)$ & $(2)$ & (3) & $(4)$ & (5) \\
\hline Afghanistan & 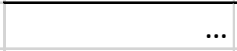 & 281 & $\ldots$ & 35,585 & 40,145 \\
\hline Albania & 76 & 77 & 1,983 & 12,745 & 12,805 \\
\hline Algeria & 384 & 411 & 1,269 & 42,020 & 44,260 \\
\hline Argentina & 105 & 174 & 3,339 & 10,185 & 16,665 \\
\hline Australia & 151 & 229 & 3,435 & 12,415 & 17,360 \\
\hline Austria & $\ldots$ & 76 & $\ldots$ & 1,650 & 4,155 \\
\hline Bangladesh & 334 & 362 & 2,971 & 38,285 & 42,130 \\
\hline Belarus & $\ldots$ & 51 & $\ldots$ & 8,535 & 9,640 \\
\hline Belgium & $\ldots$ & 122 & $\ldots$ & 4,730 & 8,665 \\
\hline Bosnia and Herzegovina & 215 & 234 & 2,397 & 29,760 & 32,955 \\
\hline Brazil & 176 & 230 & 2,639 & 19,585 & 23,445 \\
\hline Bulgaria & 127 & 148 & 2,014 & 14,940 & 15,975 \\
\hline Burma (Myanmar) & $\ldots$ & 54 & $\ldots$ & 6,055 & 7,450 \\
\hline Burundi & $\ldots$ & 59 & $\ldots$ & 5,715 & 6,085 \\
\hline Cambodia & $\ldots$ & 98 & $\ldots$ & 6,770 & 23,650 \\
\hline Cameroon & $\ldots$ & 78 & $\ldots$ & 7,320 & 7,670 \\
\hline Chile & 66 & 268 & 3,182 & 7,635 & 24,895 \\
\hline China & 3,151 & 3,830 & 4,445 & 427,865 & 518,180 \\
\hline Colombia & 532 & 593 & 6,011 & 50,415 & 55,905 \\
\hline Congo, the Democratic Republic & $\ldots$ & 164 & $\ldots$ & 16,040 & 17,470 \\
\hline Croatia & $\ldots$ & 171 & $\ldots$ & 11,890 & 21,840 \\
\hline Cuba & $\ldots$ & 112 & $\ldots$ & 11,610 & 12,475 \\
\hline Czech Republic & $\ldots$ & 113 & $\ldots$ & 4,640 & 11,505 \\
\hline Denmark & $\ldots$ & 61 & $\ldots$ & 1,445 & 3,705 \\
\hline Dominican Republic & $\ldots$ & 57 & $\ldots$ & 6,045 & 8,200 \\
\hline Ecuador & $\ldots$ & 67 & $\ldots$ & 6,490 & 13,000 \\
\hline Egypt & 231 & 338 & 6,044 & 26,435 & 37,815 \\
\hline El Salvador & 137 & 361 & 1,229 & 19,635 & 43,365 \\
\hline Ethiopia & 171 & 209 & 1,490 & 17,510 & 23,235 \\
\hline France & 698 & 975 & 1,000 & 59,545 & 78,885 \\
\hline
\end{tabular}




\begin{tabular}{|c|c|c|c|c|c|}
\hline Germany & 471 & 990 & 4,066 & 27,970 & 54,280 \\
\hline Ghana & 96 & 140 & 1,528 & 14,130 & 20,570 \\
\hline Greece & $\ldots$ & 154 & $\ldots$ & 3,095 & 22,300 \\
\hline Guatemala & 69 & 150 & 999 & 7,870 & 15,155 \\
\hline Guyana & ... & 647 & $\ldots$ & 33,775 & 79,700 \\
\hline Haiti & $\ldots$ & 621 & $\ldots$ & 44,695 & 76,075 \\
\hline Hong Kong & 706 & 1,548 & 1,231 & 100,715 & 194,535 \\
\hline Hungary & 67 & 154 & 646 & 9,340 & 17,205 \\
\hline India & 3,078 & 4,015 & 5,849 & 390,505 & 516,040 \\
\hline Indonesia & 82 & 116 & 2,895 & 7,980 & 11,370 \\
\hline Iran & 714 & 985 & 5,134 & 94,885 & 119,260 \\
\hline Iraq & 261 & 308 & 4,995 & 40,545 & 46,210 \\
\hline Ireland & $\ldots$ & 292 & $\ldots$ & 6,090 & 15,850 \\
\hline Israel & $\ldots$ & 129 & $\ldots$ & 8,940 & 15,820 \\
\hline Italy & 72 & 303 & 1,006 & 9,135 & 44,430 \\
\hline Jamaica & $\ldots$ & 1,002 & $\ldots$ & 42,915 & 106,870 \\
\hline Japan & 184 & 253 & 2,396 & 20,930 & 26,960 \\
\hline Jordan & 62 & 74 & 2,413 & 6,400 & 7,880 \\
\hline Kazakhstan & $\ldots$ & 85 & ... & 8,320 & 8,455 \\
\hline Kenya & $\ldots$ & 202 & $\ldots$ & 10,140 & 21,910 \\
\hline Korea, South & 407 & 511 & 2,370 & 95,290 & 117,610 \\
\hline Kuwait & $\ldots$ & 126 & $\ldots$ & 10,070 & 12,080 \\
\hline Laos & $\ldots$ & 95 & $\ldots$ & 2,060 & 14,270 \\
\hline Lebanon & $\ldots$ & 631 & $\ldots$ & 40,775 & 74,830 \\
\hline Malaysia & 73 & 178 & 1,199 & 9,165 & 21,290 \\
\hline Mauritius & $\ldots$ & 84 & $\ldots$ & 7,800 & 11,985 \\
\hline Mexico & 629 & 869 & 5,306 & 56,965 & 71,245 \\
\hline Moldova & 77 & 83 & 2,999 & 10,455 & 11,125 \\
\hline Morocco & 439 & 504 & 3,454 & 40,185 & 48,505 \\
\hline Nepal & ... & 72 & $\ldots$ & 7,150 & 7,275 \\
\hline Netherlands & 217 & 512 & 1,049 & 11,625 & 25,580 \\
\hline New Zealand & 63 & 122 & 2,052 & 5,090 & 8,110 \\
\hline Nicaragua & $\ldots$ & 79 & $\ldots$ & 3,855 & 8,825 \\
\hline Nigeria & 220 & 243 & 3,985 & 24,030 & 26,195 \\
\hline Pakistan & 1,083 & 1,248 & 1,693 & 121,000 & 137,865 \\
\hline Paraguay & ... & 85 & $\ldots$ & 2,020 & 4,495 \\
\hline Peru & 150 & 218 & 4,171 & 17,865 & 25,180 \\
\hline Philippines & 3,559 & 4,709 & 2,399 & 356,125 & 452,130 \\
\hline Poland & 446 & 1,453 & 989 & 50,090 & 120,975 \\
\hline Portugal & $\ldots$ & 647 & $\ldots$ & 15,155 & 94,220 \\
\hline Romania & 640 & 816 & 2,892 & 60,795 & 73,320 \\
\hline Russia & 593 & 667 & 4,031 & 60,720 & 66,140 \\
\hline Saudi Arabia & 143 & 154 & 1,494 & 16,705 & 17,875 \\
\hline Senegal & $\ldots$ & 58 & $\ldots$ & 4,635 & 4,925 \\
\hline Serbia & 137 & 175 & 1,175 & 18,555 & 25,020 \\
\hline Singapore & $\ldots$ & 83 & $\ldots$ & 5,075 & 9,810 \\
\hline Slovakia & 51 & 92 & 1,093 & 4,960 & 8,495 \\
\hline Somaliland region & $\ldots$ & 155 & $\ldots$ & 17,455 & 21,375 \\
\hline South Africa & 427 & 623 & 8,887 & 22,820 & 35,955 \\
\hline
\end{tabular}




\begin{tabular}{|l|r|r|r|r|r|}
\hline Spain & $\ldots$ & $\ldots$ & $\ldots$ & 2,625 & 5,565 \\
\hline Sri Lanka & $\ldots$ & 718 & $\ldots$ & 101,070 & 128,790 \\
\hline Sudan & $\ldots$ & 146 & $\ldots$ & 11,345 & 12,410 \\
\hline Sweden & $\ldots$ & 55 & $\ldots$ & 2,135 & 4,110 \\
\hline Switzerland & 124 & 238 & 2,429 & 6,855 & 12,830 \\
\hline Syria & $\ldots$ & 137 & $\ldots$ & 13,270 & 19,730 \\
\hline Taiwan & 347 & 450 & 2,005 & 54,295 & 64,735 \\
\hline Tanzania & $\ldots$ & 111 & $\ldots$ & 5,190 & 18,630 \\
\hline Thailand & 62 & 112 & 1,520 & 7,300 & 12,360 \\
\hline Trinidad and Tobago & 152 & 460 & 999 & 22,375 & 54,290 \\
\hline Tunisia & $\ldots$ & 119 & $\ldots$ & 9,270 & 10,670 \\
\hline Turkey & 93 & 137 & 6,630 & 17,245 & 23,130 \\
\hline Uganda & $\ldots$ & 98 & $\ldots$ & 2,770 & 11,110 \\
\hline Ukraine & 398 & 458 & 3,665 & 47,975 & 52,995 \\
\hline United Arab Emirates & $\ldots$ & 108 & $\ldots$ & 8,785 & 9,635 \\
\hline United Kingdom & 1,411 & 4,183 & 1,038 & 87,435 & 255,485 \\
\hline United States & 1,365 & 3,044 & 3,955 & 94,220 & 183,215 \\
\hline Uruguay & $\ldots$ & 65 & $\ldots$ & 2,550 & 6,060 \\
\hline Venezuela & 134 & 151 & 1,187 & 13,140 & 15,135 \\
\hline Vietnam & 240 & 815 & 2,474 & 60,625 & 163,835 \\
\hline Zimbabwe & 90 & 114 & 1,000 & 7,240 & 8,830 \\
\hline Total & 26,186 & 49,233 & 154,746 & $3,488,075$ & $5,234,660$ \\
\hline Number of countries & 56 & 100 & 56 & 100 & 100 \\
\hline Sample & & $\ldots$ & 5 & \\
\hline
\end{tabular}

a Sample includes non-permanent residents. Source: Statistics Canada, General Social Survey 2008, 2009, 2010, 2011, 2013 and 2014, and Canadian Community Health Survey 2009 to 2014.

b Source: World Values Survey, Waves 3 to 5.

c Source: Statistics Canada, National Household Survey 2011, Data tables, Immigration and Ethnocultural Diversity \#1, catalogue no. 99-010-X2011026. 
Table 2

OLS coefficients from satisfaction with life regressions

\begin{tabular}{|c|c|c|c|c|}
\hline & Unadjusted & $\begin{array}{c}\text { Unadjusted, } \\
\text { with survey } \\
\text { controls } \\
\end{array}$ & $\begin{array}{c}\text { Adjusted, } \\
\text { no health } \\
\text { controls } \\
\end{array}$ & \begin{tabular}{|c|} 
Adjusted, \\
with health \\
controls \\
\end{tabular} \\
\hline & (1) & $(2)$ & (3) & (4) \\
\hline \multicolumn{5}{|l|}{ Immigrants in Canada from: } \\
\hline Australia & $7.9 * * *$ & $7.8 * * *$ & $7.9 * * *$ & $7.4 * * *$ \\
\hline France & $8.1 * * *$ & $8.1 * * *$ & $8.2 * * *$ & $7.6 * * *$ \\
\hline Germany & $8.2 * * *$ & $8.2 * * *$ & $8.2 * * *$ & $7.7 * * *$ \\
\hline Netherlands & $7.8^{* * *}$ & $7.8 * * *$ & $7.9 * * *$ & $7.3^{* * *}$ \\
\hline New Zealand & $7.7 * * *$ & $7.7 * * *$ & $7.9 * * *$ & $7.1 * * *$ \\
\hline Switzerland & $8.2 * * *$ & $8.1 * * *$ & $8.1 * * *$ & $7.6 * * *$ \\
\hline United Kingdom & $8.0 * * *$ & $8.0 * * *$ & $8.1^{* * *}$ & $7.5 * * *$ \\
\hline United States & $8.0 * * *$ & $8.0 * * *$ & $8.0 * * *$ & $7.4 * * *$ \\
\hline Albania & $8.3 * * *$ & $8.2 * * *$ & $8.3 * * *$ & $7.7 * * *$ \\
\hline Bosnia and Herzegovina & $7.8 * * *$ & $7.8 * * *$ & $7.9 * * *$ & $7.4 * * *$ \\
\hline Bulgaria & $7.8 * * *$ & $7.6 * * *$ & $7.7 * * *$ & $7.0 * * *$ \\
\hline Hungary & $7.6 * * *$ & $7.6 * * *$ & $7.9 * * *$ & $7.3 * * *$ \\
\hline Italy & $8.4 * * *$ & $8.3 * * *$ & $8.4 * * *$ & $7.8^{* * *}$ \\
\hline Moldova & $8.0 * * *$ & $8.0 * * *$ & $7.9 * * *$ & $7.6 * * *$ \\
\hline Poland & $7.6 * * *$ & $7.6 * * *$ & $7.7 * * *$ & $7.3 * * *$ \\
\hline Romania & $8.0 * * *$ & $8.0 * * *$ & $8.0 * * *$ & $7.5 * * *$ \\
\hline Russian Federation & $7.8 * * *$ & $7.7 * * *$ & $7.8 * * *$ & $7.4 * * *$ \\
\hline Serbia & $7.7 * * *$ & $7.7 * * *$ & $7.7 * * *$ & $7.2 * * *$ \\
\hline Slovakia & $7.8 * * *$ & $7.7 * * *$ & $7.8 * * *$ & $7.1 * * *$ \\
\hline Ukraine & $7.8 * * *$ & $7.8 * * *$ & $7.8 * * *$ & $7.5 * * *$ \\
\hline Argentina & $8.4 * * *$ & $8.3 * * *$ & $8.4 * * *$ & $7.7^{* * *}$ \\
\hline Brazil & $8.2 * * *$ & $8.1 * * *$ & $8.2^{* * *}$ & $7.5 * * *$ \\
\hline Chile & $8.0 * * *$ & $7.9 * * *$ & $8.0 * * *$ & $7.6 * * *$ \\
\hline Colombia & $8.1 * * *$ & $8.1 * * *$ & $8.2 * * *$ & $7.6 * * *$ \\
\hline El Salvador & $8.1 * * *$ & $8.1 * * *$ & $8.3 * * *$ & $7.9 * * *$ \\
\hline Guatemala & $7.9 * * *$ & $7.9 * * *$ & $8.1 * * *$ & $7.7 * * *$ \\
\hline Mexico & $8.4 * * *$ & $8.4 * * *$ & $8.5 * * *$ & $8.0 * * *$ \\
\hline Peru & $8.0 * * *$ & $8.0 * * *$ & $8.1 * * *$ & $7.7 * * *$ \\
\hline Trinidad and Tobago & $7.8 * * *$ & $7.7 * * *$ & $7.9 * * *$ & $7.4 * * *$ \\
\hline Venezuela & $8.2 * * *$ & $8.1 * * *$ & $8.2 * * *$ & $7.5 * * *$ \\
\hline Algeria & $7.7 * * *$ & $7.6 * * *$ & $7.7 * * *$ & $7.4 * * *$ \\
\hline Egypt & $7.8 * * *$ & $7.7 * * *$ & $7.7 * * *$ & $7.3 * * *$ \\
\hline Ethiopia & $7.5 * * *$ & $7.5^{* * *}$ & $7.7 * * *$ & $7.0 * * *$ \\
\hline Ghana & $8.4 * * *$ & $8.4 * * *$ & $8.6 * * *$ & $7.9 * * *$ \\
\hline Iran & $7.5 * * *$ & $7.5^{* * *}$ & $7.5^{* * *}$ & $7.0 * * *$ \\
\hline Iraq & $7.2 * * *$ & $7.2 * * *$ & $7.3 * * *$ & $7.0 * * *$ \\
\hline Jordan & $7.8^{* * *}$ & $7.7 * * *$ & $7.6 * * *$ & $7.1 * * *$ \\
\hline Morocco & $7.5 * * *$ & $7.4 * * *$ & $7.5 * * *$ & $7.3 * * *$ \\
\hline Nigeria & $8.4 * * *$ & $8.3^{* * *}$ & $8.4 * * *$ & $7.7 * * *$ \\
\hline Saudi Arabia & $8.1 * * *$ & $8.0 * * *$ & $8.0 * * *$ & $7.5 * * *$ \\
\hline South Africa, Republic of & $8.0 * * *$ & $7.9 * * *$ & $8.0 * * *$ & $7.3 * * *$ \\
\hline Turkey & $7.4 * * *$ & $7.4 * * *$ & $7.5 * * *$ & $7.0 * * *$ \\
\hline Zimbabwe & $7.7^{* * *}$ & $7.6 * * *$ & $7.7 * * *$ & $7.1 * * *$ \\
\hline Bangladesh & $7.2 * * *$ & $7.1 * * *$ & $7.1 * * *$ & $6.8 * * *$ \\
\hline China & $7.5 * * *$ & $7.4 * * *$ & $7.4 * * *$ & $7.1 * * *$ \\
\hline Hong Kong & $7.5 * * *$ & $7.5 * * *$ & $7.6 * * *$ & $7.3 * * *$ \\
\hline India & $7.9 * * *$ & $7.9 * * *$ & $7.9 * * *$ & $7.5 * * *$ \\
\hline Indonesia & $7.6 * * *$ & $7.5 * * *$ & $7.5^{* * *}$ & $7.1 * * *$ \\
\hline Japan & $7.6 * * *$ & $7.6 * * *$ & $7.6 * * *$ & $7.1 * * *$ \\
\hline Korea South & $7.6 * * *$ & $7.6 * * *$ & $7.6 * * *$ & $7.2 * * *$ \\
\hline Malaysia & $7.8 * * *$ & $7.8 * * *$ & $7.8 * * *$ & $7.3^{* * *}$ \\
\hline Pakistan & $7.8 * * *$ & $7.8 * * *$ & $7.8 * * *$ & $7.4 * * *$ \\
\hline Philippines & $8.2 * * *$ & $8.1 * * *$ & $8.2 * * *$ & $7.7 * * *$ \\
\hline Taiwan & $7.9 * * *$ & $7.8 * * *$ & $7.9 * * *$ & $7.6 * * *$ \\
\hline Thailand & $8.2 * * *$ & $8.1 * * *$ & $8.2 * * *$ & $7.7 * * *$ \\
\hline Viet Nam & $7.5 * * *$ & $7.5 * * *$ & $7.6 * * *$ & $7.3^{* * *}$ \\
\hline
\end{tabular}




\begin{tabular}{|c|c|c|c|c|}
\hline Source country: & & & & \\
\hline Australia & $7.4^{* * *}$ & $7.4^{* * *}$ & $7.6 * * *$ & $6.9 * * *$ \\
\hline France & $6.9 * * *$ & $6.9 * * *$ & $7.2 * * *$ & $6.5^{* * *}$ \\
\hline Germany & $7.1 * * *$ & $7.1 * * *$ & $7.3 * * *$ & $6.8 * * *$ \\
\hline Netherlands & $7.8 * * *$ & $7.8^{* * *}$ & $8.0 * * *$ & $7.3^{* * *}$ \\
\hline New Zealand & $7.8^{* * *}$ & $7.8^{* * *}$ & $8.1 * * *$ & $7.3^{* * *}$ \\
\hline Switzerland & $8.1 * * *$ & $8.1 * * *$ & $8.3 * * *$ & $7.4 * * *$ \\
\hline United Kingdom & $7.6 * * *$ & $7.6^{* * *}$ & $7.8^{* * *}$ & $7.1^{* * *}$ \\
\hline United States & $7.6 * * *$ & $7.6 * * *$ & $7.7^{* * *}$ & $7.0^{* * *}$ \\
\hline Albania & $5.0 * * *$ & $5.0^{* * *}$ & $5.2 * * *$ & $4.6 * * *$ \\
\hline Bosnia and Herzegovina & $5.6 * * *$ & $5.6 * * *$ & $5.8 * * *$ & $5.3^{* * *}$ \\
\hline Bulgaria & $4.9 * * *$ & $4.9 * * *$ & $5.1 * * *$ & $4.7 * * *$ \\
\hline Hungary & $5.9 * * *$ & $5.9 * * *$ & $6.1 * * *$ & $5.7 * * *$ \\
\hline Italy & $6.9 * * *$ & $6.9 * * *$ & $7.1 * * *$ & $6.5^{* * *}$ \\
\hline Moldova & $4.6 * * *$ & $4.6^{* * *}$ & $4.8 * * *$ & $4.6^{* * *}$ \\
\hline Poland & $7.0 * * *$ & $7.0 * * *$ & $7.3^{* * *}$ & $6.8^{* * *}$ \\
\hline Romania & $5.4 * * *$ & $5.4 * * *$ & $5.5^{* * *}$ & $5.1^{* * *}$ \\
\hline Russian Federation & $5.3^{* * *}$ & $5.3 * * *$ & $5.4 * * *$ & $5.3^{* * *}$ \\
\hline Serbia & $6.0 * * *$ & $6.0 * * *$ & $6.2 * * *$ & $5.8^{* * *}$ \\
\hline Slovakia & $6.1^{* * *}$ & $6.1 * * *$ & $6.3 * * *$ & $5.9 * * *$ \\
\hline Ukraine & $4.4 * * *$ & $4.4^{* * *}$ & $4.6 * * *$ & $4.4 * * *$ \\
\hline Argentina & $7.3 * * *$ & $7.3^{* * *}$ & $7.7^{* * *}$ & $7.0 * * *$ \\
\hline Brazil & $7.4^{* * *}$ & $7.4^{* * *}$ & $7.8^{* * *}$ & $7.1^{* * *}$ \\
\hline Chile & $7.1 * * *$ & $7.1^{* * *}$ & $7.3 * * *$ & $6.8^{* * *}$ \\
\hline Colombia & $8.4^{* * *}$ & $8.4^{* * *}$ & $8.6 * * *$ & $8.0 * * *$ \\
\hline El Salvador & $7.5^{* * *}$ & $7.5^{* * *}$ & $7.8^{* * *}$ & $7.2^{* * *}$ \\
\hline Guatemala & $8.0 * * *$ & $8.0 * * *$ & $8.1 * * *$ & $7.6^{* * *}$ \\
\hline Mexico & $7.9 * * *$ & $7.9 * * *$ & $8.1 * * *$ & $7.6^{* * *}$ \\
\hline Peru & $6.6 * * *$ & $6.6 * * *$ & $6.8 * * *$ & $6.4 * * *$ \\
\hline Trinidad and Tobago & $7.3^{* * *}$ & $7.3^{* * *}$ & $7.6 * * *$ & $6.9 * * *$ \\
\hline Venezuela & $6.7 * * *$ & $6.7 * * *$ & $7.0 * * *$ & $6.3 * * *$ \\
\hline Algeria & $5.7 * * *$ & $5.7 * * *$ & $5.8 * * *$ & $5.5^{* * *}$ \\
\hline Egypt & $5.5 * * *$ & $5.5^{* * *}$ & $5.7 * * *$ & $5.2^{* * *}$ \\
\hline Ethiopia & $5.0 * * *$ & $5.0 * * *$ & $5.3 * * *$ & $4.8^{* * *}$ \\
\hline Ghana & $6.1 * * *$ & $6.1 * * *$ & $6.5 * * *$ & $5.7^{* * *}$ \\
\hline Iran & $6.4 * * *$ & $6.4 * * *$ & $6.5^{* * *}$ & $6.0^{* * *}$ \\
\hline Iraq & $4.8^{* * *}$ & $4.8^{* * *}$ & $5.0 * * *$ & $4.5^{* * *}$ \\
\hline Jordan & $6.4 * * *$ & $6.4 * * *$ & $6.7 * * *$ & $5.9 * * *$ \\
\hline Morocco & $5.8 * * *$ & $5.8 * * *$ & $6.1 * * *$ & $5.4 * * *$ \\
\hline Nigeria & $6.7 * * *$ & $6.7 * * *$ & $6.9 * * *$ & $6.1 * * *$ \\
\hline Saudi Arabia & $7.3^{* * *}$ & $7.3^{* * *}$ & $7.3^{* * *}$ & $6.5^{* * *}$ \\
\hline South Africa, Republic of & $5.8 * * *$ & $5.8^{* * *}$ & $6.1 * * *$ & $5.4 * * *$ \\
\hline Turkey & $6.3 * * *$ & $6.3 * * *$ & $6.5^{* * *}$ & $6.0^{* * *}$ \\
\hline Zimbabwe & $3.9 * * *$ & $3.9 * * *$ & $4.2 * * *$ & $3.6^{* * *}$ \\
\hline Bangladesh & $6.1 * * *$ & $6.1 * * *$ & $6.3 * * *$ & $5.9 * * *$ \\
\hline China & $6.7 * * *$ & $6.7 * * *$ & $6.9 * * *$ & $6.4 * * *$ \\
\hline Hong Kong & $6.4 * * *$ & $6.4 * * *$ & $6.6 * * *$ & $6.1^{* * *}$ \\
\hline India & $5.8 * * *$ & $5.8^{* * *}$ & $6.0 * * *$ & $5.5^{* * *}$ \\
\hline Indonesia & $6.9 * * *$ & $6.9 * * *$ & $7.1 * * *$ & $6.6^{* * *}$ \\
\hline Japan & $6.7 * * *$ & $6.7 * * *$ & $6.8^{* * *}$ & $6.4 * * *$ \\
\hline Korea South & $6.3^{* * *}$ & $6.3 * * *$ & $6.4^{* * *}$ & $5.8^{* * *}$ \\
\hline Malaysia & $6.8^{* * *}$ & $6.8^{* * *}$ & $6.9 * * *$ & $6.2^{* * *}$ \\
\hline Pakistan & $4.9 * * *$ & $4.9 * * *$ & $5.1 * * *$ & $4.5^{* * *}$ \\
\hline Philippines & $6.8 * * *$ & $6.8 * * *$ & $6.9 * * *$ & $6.5^{* * *}$ \\
\hline Taiwan & $6.6 * * *$ & $6.6 * * *$ & $6.7 * * *$ & $6.1^{* * *}$ \\
\hline Thailand & $7.2^{* * *}$ & $7.2^{* * *}$ & $7.5^{* * *}$ & $6.8^{* * *}$ \\
\hline Viet Nam & $6.9 * * *$ & $6.9 * * *$ & $7.1 * * *$ & $6.6^{* * *}$ \\
\hline
\end{tabular}




\begin{tabular}{|c|c|c|c|c|}
\hline GSS 2008 & & -0.1 & -0.1 & 0 \\
\hline GSS 2009 & & $0.3 * * *$ & $0.3^{* * *}$ & $0.3^{* * *}$ \\
\hline GSS 2010 & & $-0.6 * * *$ & $-0.6 * * *$ & $-0.3 * * *$ \\
\hline GSS 2011 & & 0.1 & 0.1 & $0.2^{*}$ \\
\hline GSS 2013 & & 0.1 & 0.1 & 0.1 \\
\hline GSS 2014 & & $0.5 * * *$ & $0.5^{* * *}$ & $0.5^{* * *}$ \\
\hline CCHS 2009 & & 0 & 0 & 0 \\
\hline CCHS 2010 & & 0 & 0 & 0 \\
\hline \multicolumn{5}{|l|}{ CCHS 2011 (reference group) } \\
\hline CCHS 2012 & & 0 & 0 & 0 \\
\hline CCHS 2013 & & 0 & 0 & 0 \\
\hline CCHS 2014 & & 0 & 0 & 0 \\
\hline Age - 45 & & & $-0.0 * * *$ & $0.0^{*}$ \\
\hline$($ Age - 45)/100 & & & $0.1 * * *$ & $0.1^{* * *}$ \\
\hline Female & & & $0.1 * * *$ & $0.1^{* * *}$ \\
\hline \multicolumn{5}{|l|}{ Married (reference group) } \\
\hline Common-law & & & $-0.3^{* * *}$ & $-0.3^{* * *}$ \\
\hline Widowed & & & $-0.4 * * *$ & $-0.3 * * *$ \\
\hline Divorced/separated & & & $-0.8 * * *$ & $-0.7^{* * *}$ \\
\hline Single & & & $-0.4 * * *$ & $-0.3 * * *$ \\
\hline Marital status missing & & & $-0.3+$ & -0.2 \\
\hline \multicolumn{5}{|c|}{ University degree (reference group) } \\
\hline Post-secondary & & & $-0.1 * * *$ & $-0.1^{*}$ \\
\hline High school & & & $-0.2 * * *$ & $-0.1^{* *}$ \\
\hline Less than high school & & & $-0.5^{* * *}$ & $-0.3^{* * *}$ \\
\hline Education status missing & & & $-0.3 *$ & -0.1 \\
\hline \multicolumn{5}{|l|}{ Employed (reference group) } \\
\hline Unemployed & & & $-0.4 * * *$ & $-0.3 * * *$ \\
\hline Not in the labour force & & & $-0.0+$ & 0 \\
\hline Labour force status missing & & & $-0.3^{* * *}$ & $-0.2^{* *}$ \\
\hline Health, highest level & & & & $1.1^{* * *}$ \\
\hline Health, second highest level & & & & $0.6^{* * *}$ \\
\hline \multicolumn{5}{|c|}{ Health, middle level (reference group) } \\
\hline Health, second lowest level & & & & $-0.9 * * *$ \\
\hline Health, lowest level & & & & $-1.8^{* * *}$ \\
\hline Health status missing & & & & $-0.6 * *$ \\
\hline Sample size & 180,932 & 180,932 & 180,932 & 180,932 \\
\hline R-squared & 0.192 & 0.197 & 0.215 & 0.276 \\
\hline
\end{tabular}

${ }^{* * *} \mathrm{p}<0.001,{ }^{* *} \mathrm{p}<0.01,{ }^{*} \mathrm{p}<0.05, \dagger \mathrm{p}<0.1$.

Note 1: Regressions were run with no constant. If instead they had been run with one country-intercept omitted, the R-squared would have been as reported in the table.

Note2: Weighting in regressions used to adjust for selection effects:

In years where both GSS and CCHS data are available, sample weights are divided by 2, so that those two surveys combined represent the Canadian population in that year. Furthermore, sample weights for immigrants from a given source country were adjusted so that they sum to the sample size of immigrants from that country. WVS sample weights were adjusted so that the sum of weights for a given source country equals to the size of the corresponding immigrant sample. 